\title{
Gone with the wind - a review on basidiospores of lamellate agarics
}

\author{
Hans Halbwachs ${ }^{1}$ and Claus Bässler ${ }^{2}$ \\ ${ }^{1}$ German Mycological Society, Danziger Str. 20, D-63916 Amorbach, Germany \\ ${ }^{2}$ Bavarian Forest National Park, Freyunger Str. 2, 94481 Grafenau, Germany
}

Halbwachs H, Bässler C 2015 - Gone with the wind - a review on basidiospores of lamellate agarics. Mycosphere 6(1), 78-112, Doi 10.5943/mycosphere/6/1/10

\begin{abstract}
Field mycologists have a deep understanding of the morphological traits of basidiospores with regard to taxonomical classification. But often the increasing evidence that these traits have a biological meaning is overlooked. In this review we have therefore compiled morphological and ecological facts about basidiospores of agaricoid fungi and their functional implications for fungal communities as part of ecosystems.

Readers are introduced to the subject, first of all by drawing attention to the dazzling array of basidiospores, which is followed by an account of their physical and chemical qualities, such as size, quantity, structure and their molecular composition. Continuing, spore generation, dispersal and establishment are described and discussed.

Finally, possible implications for the major ecological lifestyles are analysed, and major gaps in the knowledge about the ecological functions of basidiospores are highlighted.
\end{abstract}

Key words - basidiomycetes - propagules - morphology - physiology - traits - dispersal impaction - establishment - trophic guilds - ecology - evolution

\section{Introduction}

The striking diversity of basidiospores of lamellate agarics, and more specifically of the Agaricomycetidae ${ }^{*}$ and Russulales, is overwhelming. In this paper we will often use the word spore for brevity, but basidiospore will be meant. Size, shape, colour and wall structures have always been spore properties crucial for taxonomists. Yet, the ecological meaning is not well known by many mycologists, also because most trait functions await elucidation. Nonetheless, the traits of a spore often allow ecological interpretations (fig. 1) without knowing the species.

Field mycologists know a lot about spores and their morphological properties, being key elements for identifying fungi. But awareness about the functions of those properties in an ecological setting is less common. This review aims to give an overview of spore biology and ecology, often based on almost forgotten research in the early years of the $20^{\text {th }}$ century and on rather scarce contemporary studies.

Fungal spores belong to the most prominent microscopic particles in our environment. They are omnipresent and contribute substantially to the aerosol (Bauer et al. 2008). One cubic meter of air in temperate climates typically contains 1000-10000 fungal spores (Després et al. 2012), though

\footnotetext{
* Terms marked with an asterisk are explained in Table 3 at the end of the article
} 


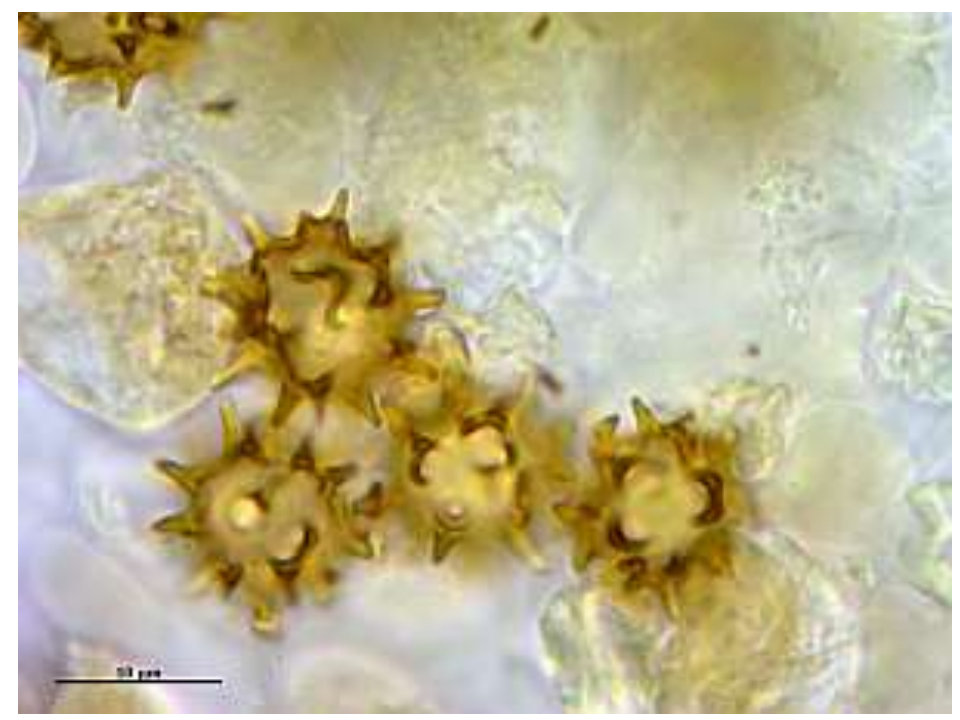

Fig. 1 - These spores are relatively small, globose, melanised, equipped with spikes and have no germ pore. This combination points at an ectomycorrhizal or saprotrophic pioneer species that is dispersed by wind over greater distances and/or by invertebrates, as we will see below. (Image courtesy of Ditte Bandini)

much greater counts have been reported during spring and fall over urban areas (Burch \& Levetin 2002, Oliveira et al. 2009). The major part are asco- and basidiospores. For example fungal spores above Mainz/Germany during 2006/2007, consisted of 34\% asco- and 64\% basidiospores of more than 1000 species. Almost 90\% of the basidiospores originated from euagarics (Agaricales) (Fröhlich-Nowoisky et al. 2009). In the following review we focus on lamellate agarics mainly of temperate and boreal ecozones.

What are basidiospores biologically? Basidiospores serve in dispersal and reproduction. They are mostly one-celled propagules (meiospores*) that are often able to survive adverse environmental conditions, and so allow sexual propagation when conditions are favourable (Kirk et al. 2011). Agaricales produce profuse numbers of spores in the order of tens of billions (Buller 1924: 403f), some gasteroid fungi ("puffballs") - such as Calvatia gigantea (Batsch) Rostk. - even several trillions ( $\mathrm{Li} 2011$ ), a truly considerable investment into reproduction.

According to phylogenetic studies fungi with basidiospores had already appeared $130-330$ million years ago during the Carboniferous, Triassic, Jurassic and Cretaceous periods, together with phanerogams (flowering plants) (Moore et al. 2011: 31-38, Oberwinkler 2012, Taylor et al. 2014:176). Some are still preserved as fossils in Cretaceous amber (Girard et al. 2009), e.g. members of the tricholomatoid family (Hibbett et al. 1997). The fossils prove that basidiomycetes are ancient organisms in evolutionary terms. The shape of agaricoid fungi has evidently changed in many details during evolution, but the blueprint is still the same. Basidiospores are typically $6 \mu \mathrm{m}$ wide and $10 \mu \mathrm{m}$ long (based on data in Knudsen \& Vesterholt 2012), chamfered and exhibit walls of varying complexity. However, in every aspect variation is considerable (fig. 2).

But not only shape underlies enormous variation, but also in size, wall thickness, ornamentation and pigmentation (Webster \& Weber 2007: 495-497). All these traits and trait combinations are most probably of functional significance (Gregory 1973: 15) for successful dispersal and germination and are deeply rooted in the phylogeny (Halbwachs et al. 2014). Therefore spore traits are of fundamental importance for taxonomy (Parmasto et al. 1987). But what all basidiospores have in common is their role as agents for sexual reproduction, thus ensuring high genetic variability (Weber 1993). Hence basidiospores are essential for the lifecycle and evolution of agarics and overall for fungal fitness (Pringle \& Taylor 2002). Moreover, long distance dispersal helps organisms with a high dispersal fitness overcome the genetic impoverishment of isolated populations (cf. Bonn \& Poschlod 1998: 277). 


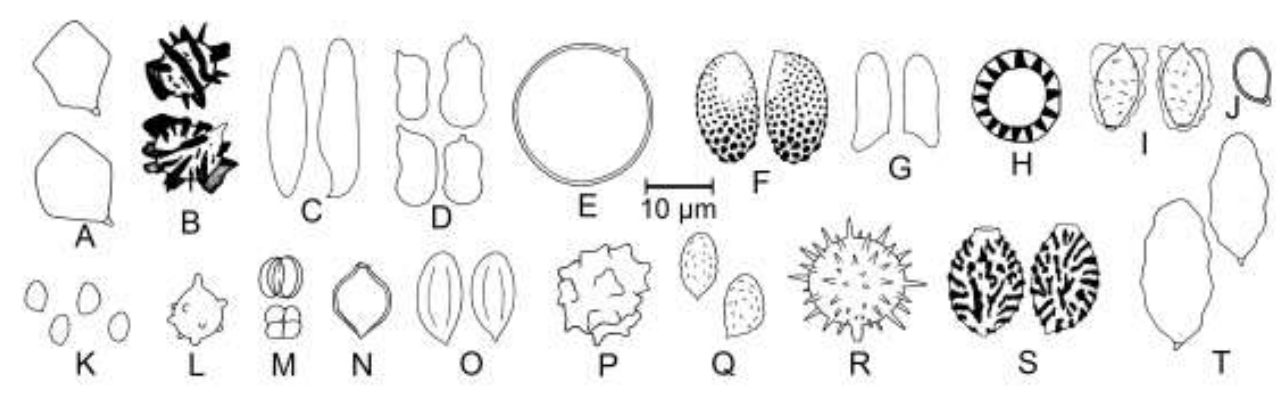

Fig. 2 - Examples of the dazzling array of basidiospores. (A) Entoloma parasiticum (Quél.) Kreisel, (B) Lactarius pterosporus Romagn., (C) Lepiota magnispora Murrill, (D) Hygrocybe quieta (Kühner) Singer, (E) Cyphella digitalis (Alb. \& Schwein.) Fr., (F) Cortinarius obsoletus Kühner, (G) Lepiota castanea Quél., (H) Fayodia bisphaerigera (J.E. Lange) Singer, (I) Coprinopsis laanii (Kits van Wav.) Redhead, Vilgalys \& Moncalvo, (J) Rhodocollybia fodiens (Kalchbr.) Antonín \& Noordel., (K) Rugomyces chrysenteron (Bull.) Bon, (L) Mycenella bryophila (Voglino) Singer, (M) Clitocybe diatreta (Fr.) P. Kumm., (N) Conocybe striatipes (Speg.) Singer, (O) Clitopilus scyphoides (Fr.) Singer, (P) Inocybe multicoronata Quél., (Q) Rhodocybe caelata (Fr.) Maire, (R) Laccaria tortilis (Bolton) Cooke, (S) Coprinus silvaticus Peck, (T) Entoloma strigosissimum (Rea) Noordel.

(Courtesy of Henning Knudsen; after Knudsen \& Vesterholt 2012)

In the following chapters we will elaborate on physiological and ecological functions that can be attributed to spore properties, based on the available literature. We first look into the basic properties of spores ("Specifications"), then into the dispersal and establishment behaviour ("Production \& distribution"), followed by an ecological interpretation of spore traits ("Market forces") and finally a comparison between lifestyles of ecological groups ("Ways of living").

The knowledge about spores is generally widely dispersed in textbooks and journal articles. In this respect the references at the end of this review constitute a comprehensive collection of pertinent literature on the function and role of spores of lamellate agarics.

\section{Specifications: characteristics of spores}

\subsection{Measures: dimensions of spores}

Rugosomyces chrysenteron (Bull.) Bon produces some of the smallest basidiospores with 2.3-3 $\mu \mathrm{m}$ length, whereas e.g. Oudemansiella mucida (Schrad.) Höhn. develop much larger spores with ca. $16 \times 16 \mu \mathrm{m}$ (Knudsen \& Vesterholt 2012). At first glance this does not look too impressive, but when one calculates the volume assuming a revolution ellipsoid* (Meerts 1999, Kauserud et al. 2008), one arrives at a variation in Agaricales of roughly $1: 350$ (based on data from Knudsen \& Vesterholt 2012).

At an intraspecific level the volume variation is typically around 20\% (based on data from Knudsen \& Vesterholt 2012), but in some taxa, e.g. in waxcaps (Boertmann 2010, Clémençon et al. 2012: 177f) it may be more than 80\%, as in Hydropus subalpinus (Höhn.) Singer. This is due to the fact that some Agaricales can develop basidia with one, two or three sterigmata (fig. 3) instead of four, sometimes even more than four (cf. Elliott 1977). Spores from 4-spored basidia are usually smaller than spores from basidia with fewer spores. Moreover, heterospory* occurs e.g. in Pseudohygrocybe sect. Firmae by developing basidia of different sizes. The larger a basidium, the larger the spores (Corner 1947). An extensive account of taxa with basidia exhibiting different spore numbers can be found in Bauch (1926). Heterospory could be an adaptation of (biotrophic) Agaricales to low-nutrient and patchy habitats (cf. Pegler \& Fiard 1978), as seems also be the case with so-called proterospores: some species produce spores at the beginning of the sporulation season, which show a simpler morphology and simpler wall structures than later spores. The latter are better equipped to survive adverse conditions (Nuss 1982). 


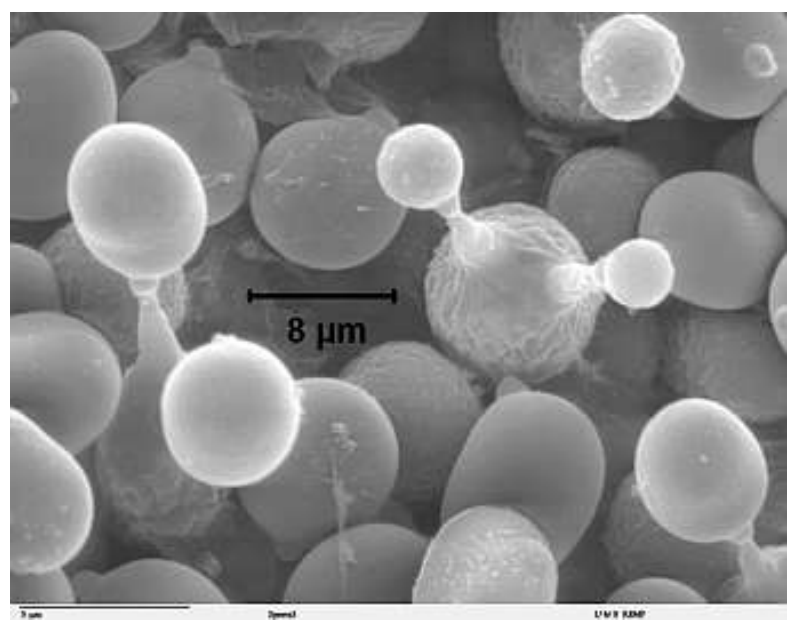

Fig. 3 - Two-spored basidium of Agaricus bisporus (public domain, http://remf.dartmouth.edu)

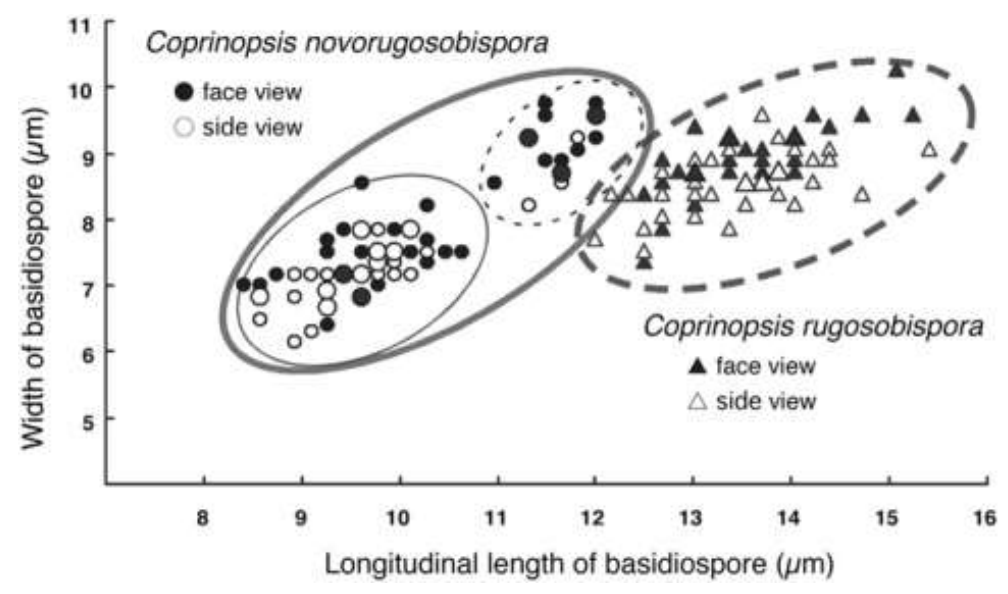

Fig. 4 - Identification of a new species using spore dimensions (courtesy of Toshimitsu Fukiharu)

Spore size and shape may also vary in certain groups, such as Amanita, with the age of the fruit body (Tanghe \& Hillhouse 1973). Senescent basidia become smaller, and so do the spores (see also Clémençon et al. 2012: 176). Moreover, small fruit bodies of e.g. Marasmius oreades (Bolton) Fr. develop significantly smaller spores than large fruit bodies (Clémençon et al. 2012: 177). Size variations may also happen when spores are exposed to moisture for too long (Gottlieb 1978: 62ff). They begin to swell, obviously as a first step of germination. The message for taxonomists is clear: for identification measure 10-20 spores from young and old fruit bodies when fresh, 25 or more when using exsiccates (Largent et al. 1978: 101f), and suspend spores in an isotonic solution, if in doubt (Erb \& Matheis 1983: 13).

Regardless of intraspecific variations spore size is a fundamental characteristic in morphological taxonomy (Parmasto et al. 1987), and is still used for separating even closely related species, despite or in addition to modern molecular methods, as for example in Coprinopsis (fig. 4, Fukiharu et al. 2012).

\subsection{Numbers'game: spore quantities}

As already mentioned, agarics invest much effort into producing high numbers of spores. Large fruit bodies generally produce more spores than small ones, because they possess larger hymenial areas, and consequentially more basidia that produce spores (cf. Fischer \& Money 2010). One may expect that smaller fruit bodies produce smaller spores to compensate for the reduced hymenial surface. We have indeed found such a tradeoff, albeit a rather negligible one (Bässler et al. 2014). Agarics have various means to increase spore density on an hymenium, e.g. by producing elongate spores or a multi-layered arrangement of the basidia (see also "Production line" below). 
In any case, the staggering spore numbers spark the question why. As we do not drown in mushrooms, e.g. in Agaricus campestris L., it appears that basidiospores have only limited chances of surviving (Brundrett 1991). This indicates a classical tradeoff: sexual propagation in agarics is an indispensible mechanism in addition to vegetative propagation, as it is the case in other higher organisms in order to maintain genetic flexibility, i.e. adaptability (Nentwig et al. 2009: 2). Below we will have a closer look into the survivability of basidiospores and other factors which cause spore wastage.

\subsection{Architecture: spore structure}

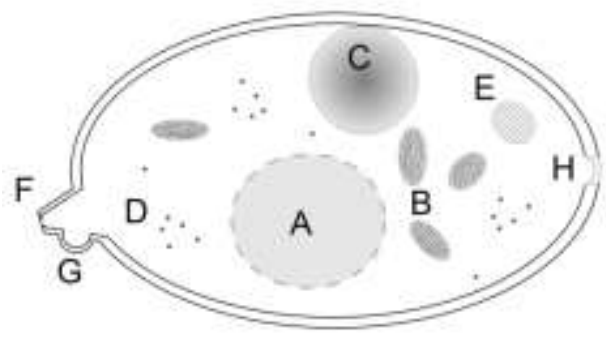

Fig. 5 - Blueprint of spores. (A) nucleus; (B) mitochondria; (C) lipid drop; (D) ribosomes; (E) nutrient vesicle; (F) hilum; (G) hilar appendix (apiculus); (H) germ pore. Drawing based on Hawker \& Madelin (1976), Clémençon et al. (2012) and Jastrow (2013)

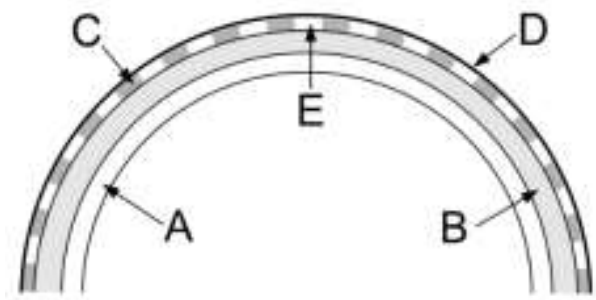

Fig. 6 - General spore wall structure. (A) endosporium; (B) episporium; (C) exosporium; (D) ectosporium; (E) perisporium. Drawing based on Clémençon et al. (2012) and Largent et al. (1978)

The basic anatomy of spores is generally the same for all agarics: a more or less ovoid cell protected by a sometimes complex wall, a hilum (left by the separation of the spore from the sterigma) with a hilar appendix and in many taxa a germ pore, by and large opposite the hilum (see fig. 5). Spore walls (fig. 6) consisting of an endosporium, episporium (eusporium) and an ectosporium are typical for smooth and colourless (hyaline) basidiospores (Clémençon et al. 2012: 180). The ectosporium is extremely thin and becomes a slimy, sticky surface in mature spores. The eusporium is mainly a fabric of interwoven microfibrils consisting of chitin and glucan, both polymer polysaccharides (Bartnicki-Garcia 1968, Ruiz-Herrera 2012). Therefore both, the endoand episporium are resistant to hot potassium hydroxide contrary to protein-dominated wall structures, as in coloured spores (Clémençon et al. 2012: 180f). In coloured spores the episporium is followed by a pigmented exosporium and a perisporium (myxosporium). In ornamented spores the exosporium is structured, as is the case with most Cortinariaceae. The perisporium may contain starchy substances (amyloids) which react with iodine. Pigmented (melanised) spores always have thicker walls than hyaline ones, and thick-walled spores often exhibit germ pores mostly opposite the apiculus, but almost only in saprotrophic taxa, as Halbwachs et al. (2014) found. The plage (or hilar depression), a smooth oval area adjoining the apiculus at the adaxial side (the side pointing at the longitudinal axis of the basidium), plays a crucial role in spore release (see "Production and distribution"). Finally it should be noted that hydrophobic basidiospores may carry electric charges (Gregory 1957, Swinbank et al. 1964) because of their insulating properties (Gow \& Morris 1995), probably to avoid clumping during discharge (Gottlieb 1978: 6). 


\subsection{Appearance: external features}

We have already mentioned the diversity of shape, pigmentation and ornamentation. Spores can be spherical (globose), ellipsoid to bean- and sausage-shaped (phaseoliform, allantoid), resemble almonds (amygdaloid), lemons (citriform) or pears (pyriform) and may even be polygonal (entolomatoid) (cf. fig. 2). They may be hyaline-colourless or lightly coloured (e.g. pink), yellowish, greenish (see fig. 7), beige, brown or almost black.

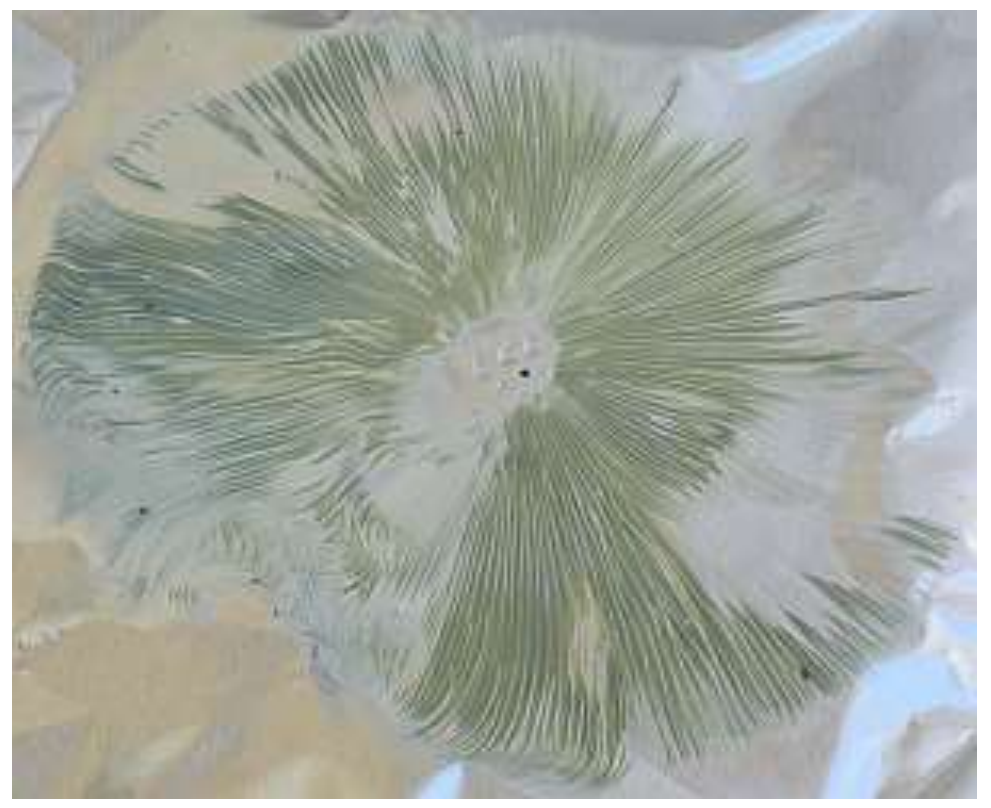

Fig. 7 - Greenish spore print of Chlorophyllum molybdites (G. Mey.: Fr.) Massee, a North American species (author byrain, CC-licenced, http://mushroomobserver.org)

The spore surface may be smooth to rough (rugose), warty (nodulose), tubercular-netlike (reticulate), with membranous appendages (epicutis, calyptra) or spiny. The interior of these spores may appear under a light microscope as unstructured or grainy, and may contain vacuoles and lipid droplets.

In combination with the size range it becomes clear that spores are one of the most useful features for identifying agarics, at least to genus level. Comprehensive accounts of spore shapes and morphological features can be found in Knudsen \& Vesterholt (2012) and in Clémençon et al. (2012).

\subsection{Intrinsic values: spore contents}

Spores contain a highly complex soup of proteins, nucleic acids, sugars, lipids, other organic compounds, inorganic ions (salts) and organelles (http://en.wikipedia.org/wiki/Cytoplasm, and see fig. 5). Electron microscopy reveals intricate organelle structures mainly comprising mitochondria (cellular "power plants", where respiration and the generation of chemical energy takes place), ribosomes ("protein factories"), and nuclei, which carry the genetic material (DNA > genes > chromosomes) (Hess \& Weber 1976, McLaughlin 1982). All these organelles "cooperate" so as to allow germination, i.e. development of germ tubes, and finally to enable sexual reproduction by outcrossing (see "Production \& distribution"). Apart from ingredients that keep a cell going (DNA, RNA, nucleic acids, enzymes, amino acids, energy transmitters, inorganic ions etc.; cf. Gottlieb 1978) spores contain important nutrients needed for germination including glycogen and lipids* (Van Etten et al. 1983) and often trehalose, a sugar which has additional virtues: it protects the cytoplasm amongst others by acting as an antifreeze (Carlile et al. 2001: 233). Trehalose together with "heat shock proteins" might also be involved in heat tolerance (Jennings \& Lysek 1999: 93f). 


\section{Production \& distribution}

\subsection{Basidiospore biography: the life-cycle of a basidiospore}

Agaricomycete spores are typically generated during a development cycle that ensures recombination of genetic material. It all starts with the development of a fruit body and a hymenium, covered with basidia, where the spores are formed. The spores are liberated, travel, and eventually get attached to a suitable substrate. If conditions are favourable the spores germinate and develop germ tubes (hyphae), which may meet, fuse and form a new mycelium (fig. 8).

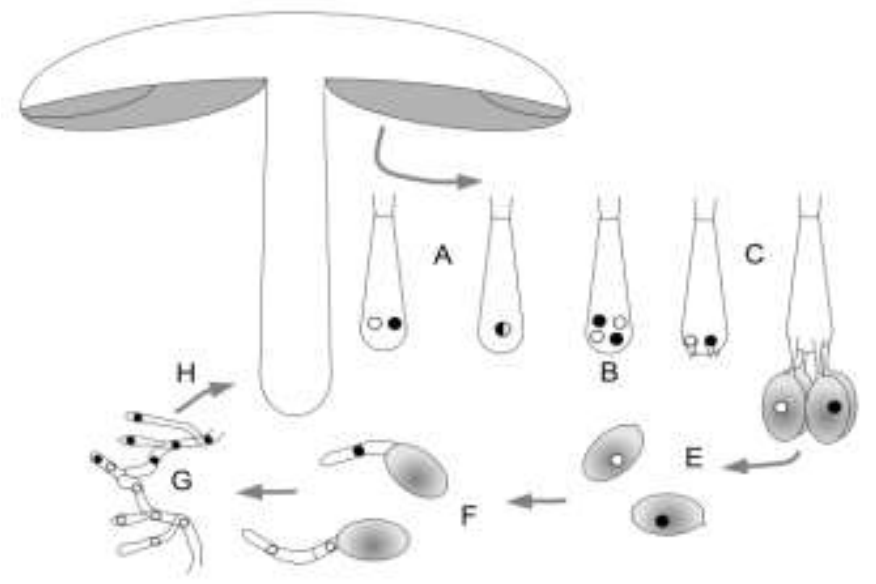

Fig. 8 - Simplified basidiomycete lifecycle: (A) fusion of nuclei in a dikaryotic* basidiole; (B) reduction division (meiosis); (C) formation of basidium and spores; (E) liberation and dispersal; (F) germination, formation of haploid* hyphae; $(\mathrm{G})$ fusion of haploid hyphae (anastomosis*), formation of a dikaryotic mycelium; $(\mathrm{H})$ fructification and hymenial development. After Dörfelt \& Jetschke (2001: 43f) and Moore et al. (2011: 204).

Sex sells: The whole point of this - in real life an even more complicated process - is to generate novel gene sets by nuclear division and basically random recombination, i.e. to improve adaptive flexibility.

Apart from these general processes, each step entails numerous physiological mechanisms, such as spore production, discharge, dispersal, impaction, dormancy and germination, which are controlled by specific fungal traits and environmental factors.

\subsection{Production line: how spores are produced}

How are the gigantic numbers of often complex spores of the agarics produced? The basic machinery consists of the basidia, which form the outer layer of the hymenium. The hymenium is part of the fruit body and transfers nutrients to the basidia and finally the spores. The fruit body mechanically keeps the hymenium in a position above the substrate allowing optimal dispersal of spores. But the fruit body serves more functions in order to optimise spore production and dispersal (Halbwachs \& Bässler 2012):

- it protects the hymenium from excessive precipitation and from desiccation by its water content and through shading (Buller 1909: 24).

- it may keep predators off by developing repelling substances, sometimes accompanied by conspicuous colours, and/or a tough pileipellis* or a surface armed with deterring scales, cystidia, setae* and the like (Taylor \& Alexander 2005)

- in some species it may attract predators that act as vectors*, e.g.either using insects as spore carriers (cf. Schigel 2012) or having the mushroom (including the spores!) eaten and excreted e.g. by sqirrels (Pyare \& Longland 2001).

- often fruit bodies are geotropic* and adjust the position of the hymenium after a disturbance by tilting the cap accordingly (Hudson 1991: 49f), to allow free fall of spores. 


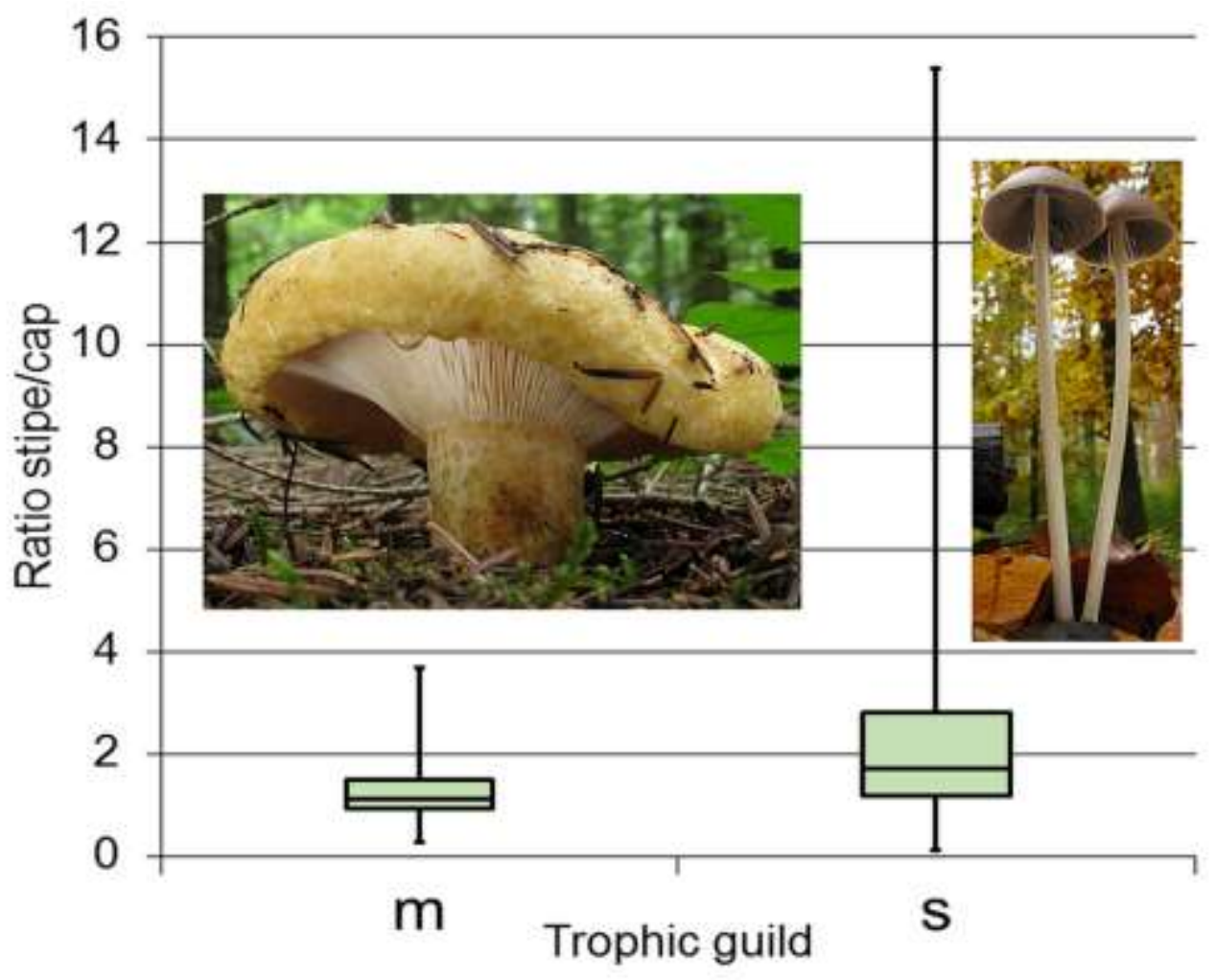

Fig. 9 - Boxplots of the relation between stipe length and cap diameter in ectomycorrhizal (m) and saprotrophic (s) fungi. The whiskers denote all values within the upper and lower $25 \%$ of the data set (279 ectomycorrhizal and 330 saprotrophic agarics taken from Knudsen \& Vesterholt (2012)). The boxes are horizontally divided by the median. The graph clearly shows the highly significant difference between the guilds. The mushroom to the left is a Lactarius scrobiculatus (Scop.) Fries, to the right two Psilocybe semilanceata (Fr.) P. Kumm. (Photographs courtesy of Georg Müller, www.pilzepilze.de)

On average fruit bodies of ectomycorrhizal fungi are larger than of saprotrophic ones ${ }^{1}$ (Bässler et al. 2014). Small fruit bodies need to grow to a height that allows wind dispersal, resulting in a relatively large ratio of stipe to cap, or in other words, resulting in a slim build (fig. 9). Though statistically highly significant, the differences of the medians are not that conspicuous. But what is striking is the asymmetrical data distribution of the saprotrophic guild, it shows a remarkable tail of high stipe-cap ratios. We might see here evolution at work, a trend towards slim build.

The greater the number of basidia, the greater the spore production, but there must be enough space between neighbouring basidia to allow all spores a clear release path. One way to increase the density of basidia is to have them of different lengths (fig. 10), with spores discharged successively, starting with those from the longest basidia and finishing with those from the shortest ones (Ramsbottom 1977: 95).

The function of the basidia as spore factories is in many cases promoted by hymenial cystidia. These have species-specific properties and serve various functions. In e.g. Coprinopsis spp. they seem to keep the gills apart during formation (Buller 1924: 285-290, Moore et al. 1998), and they may aid in keeping up humidity by acting as air traps (Largent et al. 1978: 71). They may simply be spacers to keep basidia sufficiently apart (Moore et al. 1998) as basidioles do or, finally, act as defense against predators, such as collembola (springtails) (Buller 1909: 19f, Nakamori \& Suzuki 2007). Paraphyses* may serve similar purposes.

\footnotetext{
${ }^{1}$ Note that these statements (and those to follow) are based on statistical analyses: there are always exceptions!
} 


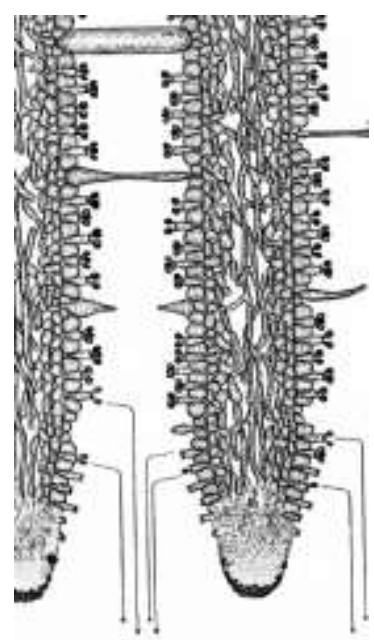

Fig. 10 - Cross-section through lamellae of Coprinopsis atramentaria (Bull.) Redhead, Vilgalys \& Moncalvo with cystidia in different stages of autolysis, dimorphic basidia and spore trajectories. After Buller (1922: 287)

\subsection{Dispatch: how spores are dispersed}

Sporulation is a complex process, involving specific genes, hormones, trigger molecules and control mechanisms tied to light and nutrition, to allow for optimal timing (Dahlberg \& Etten 1982). In Agaricales we observe two different ways to liberate spores. Ballistospores are violently shot off basidia, thus travelling horizontally for $0.04-1.83 \mathrm{~mm}$ (fig. 10) at a speed of up to $1.8 \mathrm{~m}$ per second (Fischer et al. 2010a). Gasteromycetes produce statismospores (Dring 1973) which, contrary to ballistospores, separate from broken down basidia within the fruit body, and are generally liberated by rain drops splashing on the "bellows" formed by the peridium* ("puff balls"!).

It took considerable time to unravel ballistospore mechanics. Brefeld (1877) believed that the bursting of sterigmata caused discharge and Corner (1948) speculated about a squirting basidium ("ampoule effect"). However, Buller (1909, 1922, 1924) had already suspected that the conspicuous drop at the base of a spore ("Buller's drop") somehow propels the spore by surface tension. It was only in the nineties that Turner \& Webster (1991) found out how spores are launched. It is all due to condensation of moisture and indeed surface tension: a water drop forms at the hilar appendix and a flat, less voluminous adaxial* drop condenses close to the hilum (fig. 11), a smooth, sometimes flattened spot (hilar depression) forming the plage* in ornamented spores. Within seconds the drops swell and finally fuse. This leads to a sudden transfer of mass to the spore proper, resulting in a push that snaps the sterigma, a mechanism called "surface tension catapult" (Webster \& Weber 2007: 493).
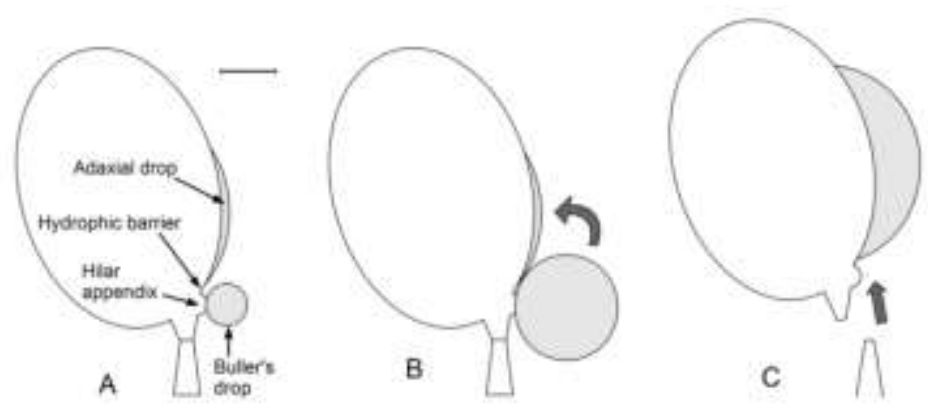

Fig. 11 - The surface tension catapult in action: (A) The two drops condense at spots coated with sugars (hydrophilic!), kept apart by a hydrophobic gap (Pringle et al. 2005). (B) Drop sizes increase until they touch and rapidly merge. (C) The momentum of merging severs the spore from the sterigma. (Scale bar: $2 \mu \mathrm{m}$ ). Drawing based on photographs and high-speed videos of Webster et al. (1984) and (Pringle et al. 2005). 


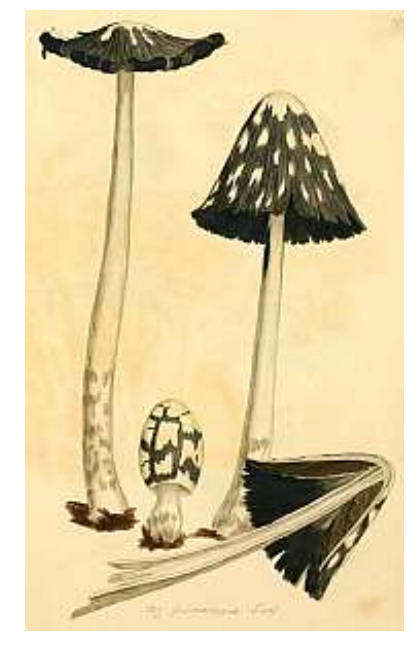

Fig. 12 - Coprinopsis picacea (Bull.) Redhead, Vilgalys \& Moncalvo (Sowerby 1797)

Question: What initiates sporulation and what controls its timing? The most important prerequisite is high humidity at the surface of the hymenium to form the catapulting drops, probably the reason why most agarics have dense hymenial gills or narrow tubes (Ingold 1966), particularly in dry habitats (Moser 1993). Ripening of the spores sets in when the stipe is fully elongated, a process controlled by the growing hymenium of probably most agaricomycetes (Manachère et al. 1983). Ballistospores, when ripe (i.e. upon closure of the eusporium), start to get discharged when the humidity reaches saturation (Ingold 1966). Maturation of spores generally starts at the gill edge and moves upwards, which enables consecutive discharge (Carlile et al. 2001: 63). In e.g. Coprinus the "used" basidia and the subhymenium even undergo self-digestion and melt away as a blackish fluid (ink) (Kendrick 1985: 129f) (cf. fig. 12).

There are some exceptions, as for example groups of basidia maturing at different times in Panaeolus papilionaceus (Bull.) Quél., giving the gills a mottled appearance (Buller 1922: 251259). The mottling is obviously controlled by the mushroom and seems only to occur with darkspored taxa. The physiological and ecological meaning of this feature still awaits elucidation. In Amanita spores mature diagonally: from the upper part of the gill moving from the stipe towards the cap margin (R.E. Tulloss, pers. comm.). The mottling and diagonal spore ripening may be alternative ways to minimise obstructions during discharge. There might be another advantage to both mechanisms: spore grazers may be less successful with mottled gills than with those starting spore maturation at the edge, and the Amanita-type of discharge mostly combined with a veil, which bar small invertebrates, may have a similar benefit. The simplest mechanism to maximise spore numbers and at the same time to optimise space for discharge is the asynchronous ripening of basidia, so that spore-bearing and spore-less basidia (basidiola) are intermingled (Moore 1998: 319).

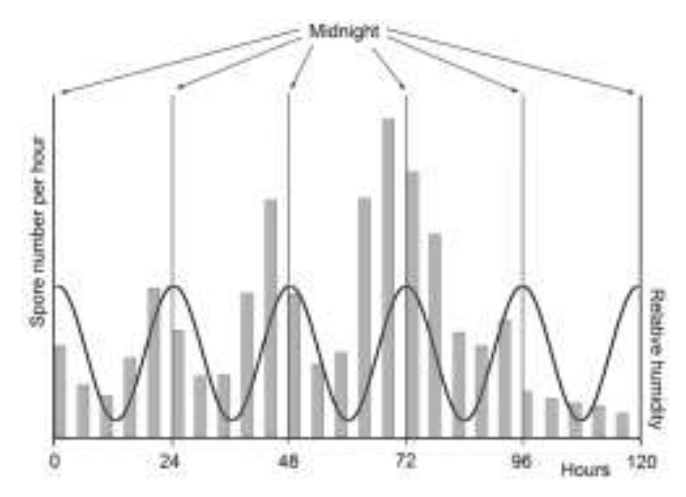

Fig. 13 - Sporulation rhythms are correlated with humidity, usually highest around midnight. Schematic based on Kramer (1982). 
The time span during which the spores are shed - and thereby the number of spores depends on microclimate and longevity of the fruitbody (Gregory 1973: 49). Dry-tolerant fruit bodies generally stay productive longer than dry-intolerant ones (cf. McKnight 1990). As an overall rule it can be assumed that the larger a fruit body, the longer it survives, because of more water and nutrients stored in the trama (Moore et al. 2008). Typically agaricoid fruit bodies maintain disseminability for a few days, sometimes even for a few weeks (Richardson 1970, Moore et al. 2008). Some taxa, for example Xerocomus and Macrolepiota, probably minimise water loss by having a tough or insulating cortex, others such as Gliophorus minimise evaporation by a gelatinous pileipellis. In genera with small mushrooms, e.g. Mycena, a high number of spores are dispersed during a short period of time through the production of many fruit bodies at once. This behaviour is typical for r-selected fungi that follow a ruderal strategy in having a short lifespan and rapid reproduction in disturbed environments. In contrast the combative or competitive life strategy entails a long life expectancy in less disturbed habitats (K-selected) (Dix \& Webster 1995: 5-9).

Larger agarics disperse spores over a longer period of time, but not necessarily evenly. First of all the overall spore production during the lifetime of a fruit body mostly follows a pattern that corresponds to an asymmetrical bell curve. Sporulation either slowly reaches a maximum and decreases sharply towards the end of the lifespan of the fruit body, or sporulation quickly reaches its maximum and then tapers off as in Amanita muscaria var. alba (Li 2005). This process is largely controlled by microclimate, particularly humidity. Spore discharge is subject to diurnal rhythms, reaching maxima approaching midnight (e.g. in Amanita: Li 2005), when ambient temperature is lowest and consequently humidity is highest (fig. 13), especially during dry weather (Haard \& Kramer 1970, Kramer 1982, Lacey 1986).

\subsection{Delivery: how spores reach their substrate}

Now that the spore is free to go it needs a vehicle (vector) or agent to get dispersed and eventually delivered to an adequate substrate and habitat. Kendrick (1985: 120) wrote "Fungi cannot walk or run, but some can swim, most can soar, a few can jump, and some must be carried". Basically there are three agents: turbulent air (wind dispersal), precipitation and animals (Ingold 1953). "Piggyback" dispersal by seeds is common in fungal plant pathogens (Ingold 1953: 151159), and has only recently been suggested for an agaric (Tello et al. 2013).

Air movement is the most common vehicle for agarics (fig. 14). Especially tall stipes (Buller 1909: 39-46) and small and/or oblong spores (see above) could then be of advantage. Although $90 \%$ of spores do not travel farther than $100 \mathrm{~m}$ (Lacey 1996, Peay et al. 2012), some reach other continents (Burnett 2003: 124, Geml et al. 2012). Most ectomycorrhizal basidiospores are rather sedentary and deposit within one meter of release (Galante et al. 2011, Horton et al. 2013) in their typical forested habitats with low wind speeds (Mitscherlich 1971: 10-17, Malloch \& Blackwell 1992). Some mushrooms use a cleverly engineered trick to overcome still air. They induce wind dispersal by evaporating water which causes differences in air temperature beneath the hymenium, leading to a minute but sufficient draft to carry the spores away (Dressaire et al. 2013). This phenomenon could also be relevant to the observation of several early scientists (see Buller 1909: 218f) that fruit bodies can significantly heat up, e.g. due to insect larvae.

Fruit body size and shape are important determinants for air dispersal. The stipe must be long enough to allow air turbulence carry away the falling spores over the several millimetres thick so-called boundary layer of still air above the ground (Burchill 1966, Gregory 1973: 32f, Galante et al. 2011). There is a danger when turbulence is high: spores my be blown back into the hymenium. This is minimised by a bell-shaped cap (Deering et al. 2001). Some mushrooms, e.g. certain Hygrocybe species, seem to show a mechanism which enables them to grow longer stipes when surrounding vegetation (e.g. grasses) is high. They continue to grow when the cap still touches plants, and possibly due to being stereotactic* the fruit bodies exhibit a swaying motion during elongation, as image recordings show (G. Griffith, pers. comm.). 


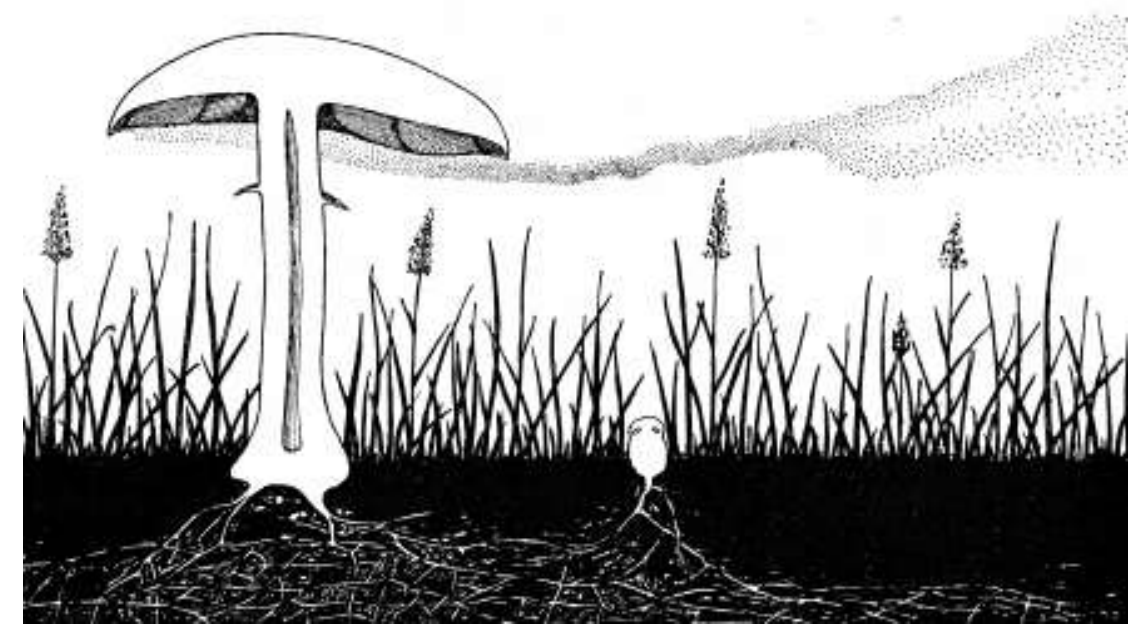

Fig. 14 - This charming schematic drawing, with a touch of art nouveau, depicts a field mushroom (Agaricus campestris) releasing spores into an air draught. Image taken from Buller (1909: 218).

Every flight ends with landing, a critical phase in the career of a spore. Impaction, i.e. the more or less forceful and lasting contact with a suitable substrate, is largely a random event with minimal chances of hitting the right spot (Gregory 1966: 9). But some spore traits facilitate the process, e.g. large spores do not easily circumvent obstacles such as tree trunks, which is especially important for wood inhabiting fungi (Kauserud et al. 2008). Rough spore surfaces and protrusions as in Russula (fig. 15) may improve attachment to substrates (Jennings \& Lysek 1999: 121, 124).

The odds of hitting a suitable substrate in a suitable habitat are minute. In hymenomycetes one in a billion spores may become established (Burnett 2003: 125f). In this respect it is a largely stochastic process, which leads to local variation of fungal communities (Peay \& Bruns 2014).

Animals are probably the most important vector after air, and not only for coprophilous fungi, and certainly for ectomycorrhizal fungi (Brundrett 1991, Lilleskov \& Bruns 2005). Any mycophagous creature may disperse spores either by ingestion or by passive transport. Known fungus consumers are mammals (Claridge \& Trappe 2005, Schickmann et al. 2012) such as rodents (Fogel \& Trappe 1978), deer (Ashkannejhad \& Horton 2006) and squirrels (Maser \& Maser 1988). Johnson (1996) suggested that mammals are very effective vectors for ectomycorrhizal fungi. In some North American coniferous forests small mammals alone consume almost $1 \mathrm{~kg}$ of agaric fruit bodies during fall (figure extrapolated from Zellner 1907: 10, North et al. 1997). Small mammals are prey for birds, such as the Northern Spotted Owl (North et al. 1997), thus potentially extend the dispersal range. Mammals as fungal vectors seem to play a crucial role in the housekeeping of ecosystems, as suggested for Australian habitats (Fleming et al. 2014).

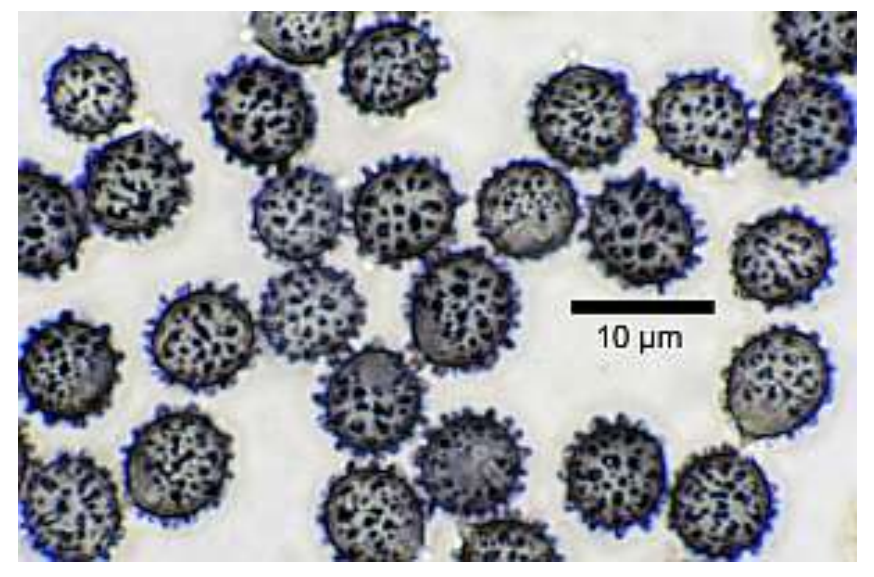

Fig. 15 - Russula grata Britzelm. with scabrose ornamentation (author Linas Kudzma, CClicenced, http://mushroomobserver.org) 


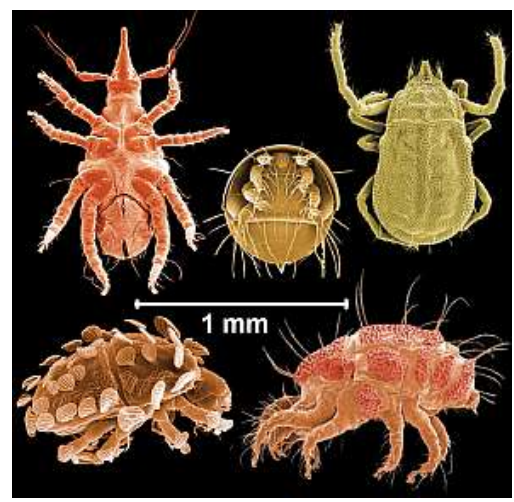

Fig. 16 - Mites of the order Prostigmata are commonly present in soils. Note the diversity of hairs and other protrusions (after Jeffery et al. 2010: 107). Reuse permitted by the EU (http://ec.europa.eu/geninfo/legal_notices_en.htm)

Slugs are avid fungivores (Frömming 1940), particularly those of the Genus Limacidae (Wiese 2014: 206), and are effective vectors (Keller \& Snell 2002), which even stimulate spore germination by gut enzymes (Spooner \& Roberts 2005: 130). Dispersal may be indirect - via toads eating slugs (Buller 1909: 227). Moreover mushroom-inhabiting insects such as fungus flies and fungi-inhabiting beetles (Henneberg 2004), and trama-eaters such as dung beetles (Hanski 1989, Gange \& Bower 1997) and particularly soil invertebrates including arthropods such as springtails and mites (Lussenhop 1992, Shaw 1992) and potentially worms (Hutchinson \& Kamel 1956) are reported to be spore vectors. In any case, the passage through digestive tracts is a tremendous challenge for spores. They must withstand aggressive chemicals, e.g. hydrochloric acid in mammalian stomachs, and a whole army of enzymes and bacteria. Therefore spores using fungivores as vectors must have thick, protective walls, often re-enforced by melanins*. Melanin synthesis is complex (Rast et al. 1981) and therefore costly for the fungus, but the protective benefits seem to be worth it.

Soil arthropods may play an important role in disseminating ectomycorrhizal fungi (Lilleskov \& Bruns 2005) because of their need to reach host fine roots. One mechanism could be analogous to the transport of hydrophobic spores by water droplets (see below). The cuticle of insects is often covered with a wax layer and rough, rendering it hydrophobic (Wigglesworth 1957). It is therefore likely that hydrophobic spores become attached. Spores with spines, nodules etc. may get stuck in hairs, spikes etc. of e.g. mites (fig. 16) and springtails (as in Tomentella sublilacina, see Lilleskov \& Bruns 2005), becoming eventually brushed off when the animals move underground. Finally many soil arthropods ingest but do not digest ectomycorrhizal spores, a dispersal mechanism thought to be important for forest ecosystems, because it assists in recovery after disturbance (cf. Maraun et al. 1998).

All these vectors disperse to different extents in terms of distance and soil depth (see fig. 17, 18). For a compilation of vectors and agents that disperse spores please refer to Table 1.

Precipitation is a possibly underrated agent for spore dispersal. This does not only apply to riparian forests* where frequent flooding occurs (Weber 1993: 283), but most probably to ectomycorrhizal spores (cf. Spooner \& Roberts 2005: 191), which are deposited close the fruit bodies (Galante et al. 2011). These spores need to reach rootlets of suitable hosts, which could well happen by leaching during rainfall (Malloch \& Blackwell 1992). Rain can be a quite effective spore scrubber, if intense enough (Gregory 1973: 121, Henis et al. 1987), depositing air suspended propagules onto any substrate or being intercepted in forests by trees.

Trees then often drain surplus rain along the branches and the trunk (Crockford \& Richardson 2000), thus probably transporting spores close to potential host roots by a channelling effect, e.g. in beech stands down to more than $30 \mathrm{~cm}$ covering a radius of ca. $4 \mathrm{~m}$ (Schwärzel et al. 2012). The channelling effect could constitute an important spore dispersal mechanism in forests and for single trees and brushes, particularly in arid habitats (cf. Li et al. 2009). 


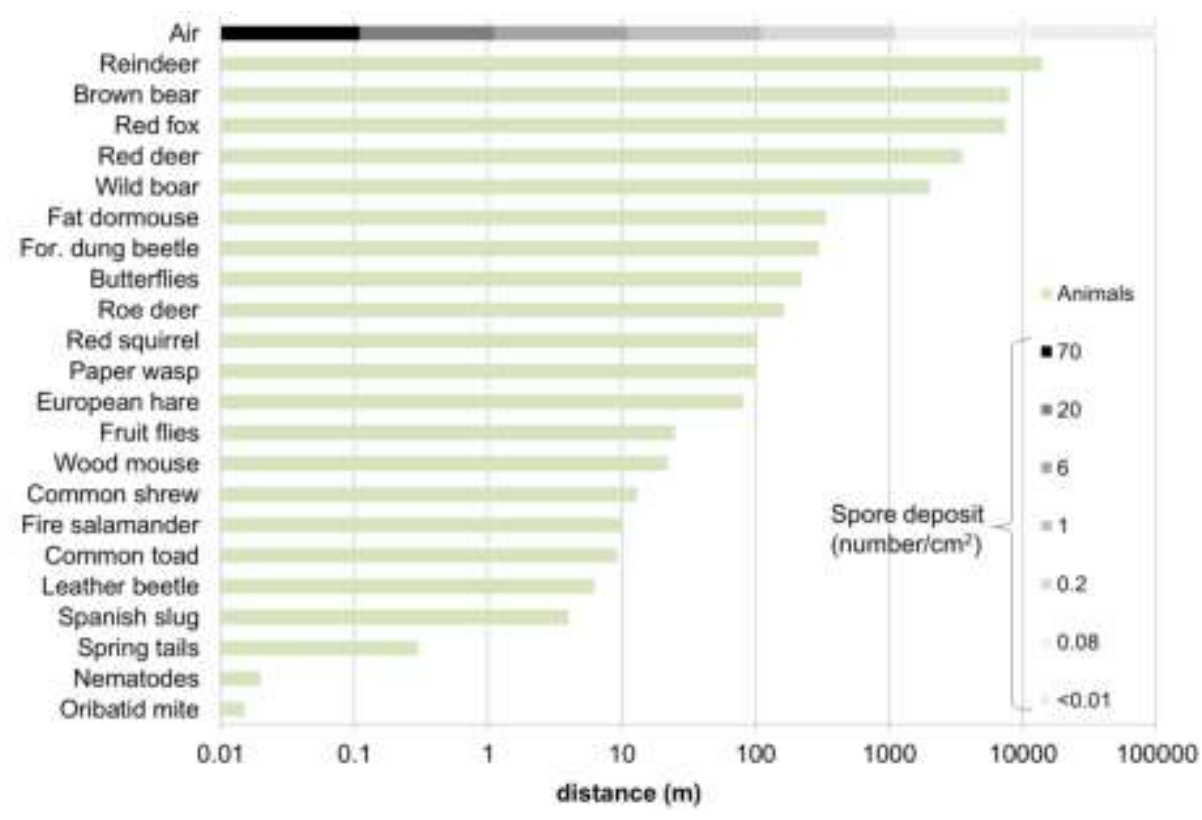

Fig. 17 - Comparison of linear dispersal potentials of air and animals (sources see Table 1)

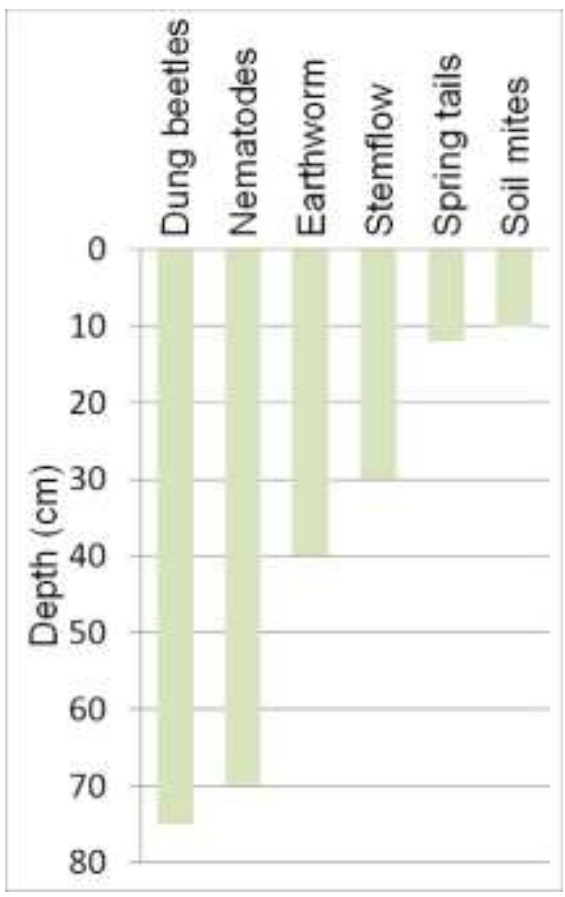

Fig. 18 - Comparison of soil depths reached by various vectors (Anoplotrupes stercorosus, Nematoda, Lumbricus terrestris, Mesaphorura, Steganacarus) and by stemflow (root channeling) (sources see Table 1)

Another dispersal mechanism is transport of spores by mist (Gregory 1973: 67). This works because of hydrophobic ornamentation, creating a "Lotus effect" by a surface roughness at the nano scale (Spori et al. 2008). Differences in the electrical charge of water droplets and spores would then create attraction and finally adhesion (cf. Davies 1961, Gregory 1973: 120). Mist can only translocate spores, deposition takes place by vegetation (e.g. coniferous forests) that intercepts and condenses the droplets, leading to "fog-drip" (Shuttleworth 1977) down to the ground.

Smooth hydrophilic spores are typical for arid areas where wind is the predominant dispersal agent (Kreisel \& Al-Fatimi 2008), although hydrophobic smooth spores do occur (Dörfelt $\&$ Ruske 2010), most probably due to the chemical composition of the exosporium. 
Table 1 Spore vectors and their ranges. Literature data on horizontal or vertical ranges of animal vectors are scarce and determined with varying methods and scales. It should therefore be noted that this compilation may not be exhaustive. Not knowing the excretion frequency of the taxa nvestigated we took as range proxy the format "mean daily displacement (MDD)", where available. For taxa for which only home range data (areas) are available we took the radius of the equivalent circle. Data are given as means, when possible and expedient. In certain cases numerical values had to be extracted from graphs. The vertical distribution of grassland invertebrates is described in (Frenzel 1936). For more literature on vectors refer to Table 4 after References.

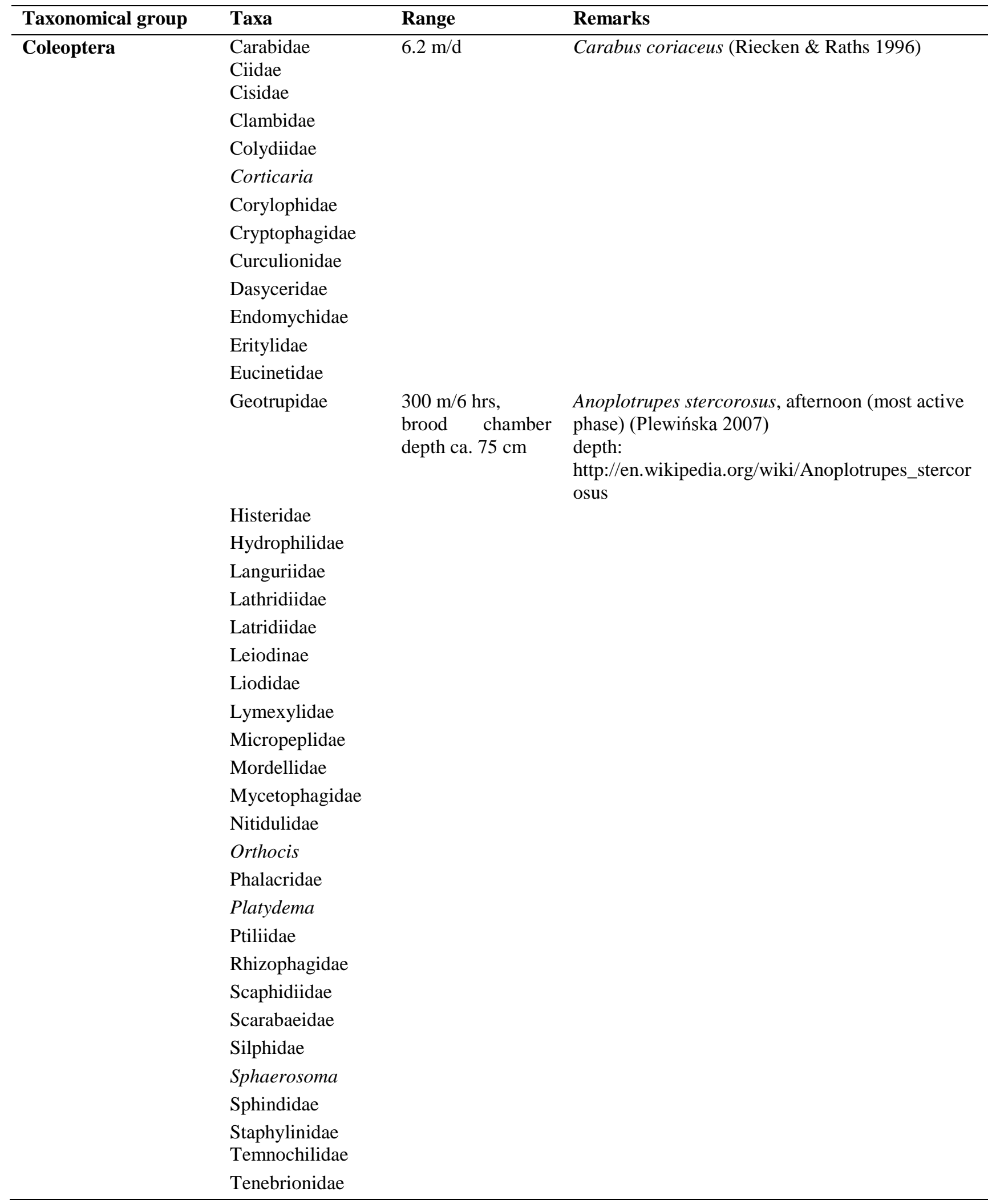




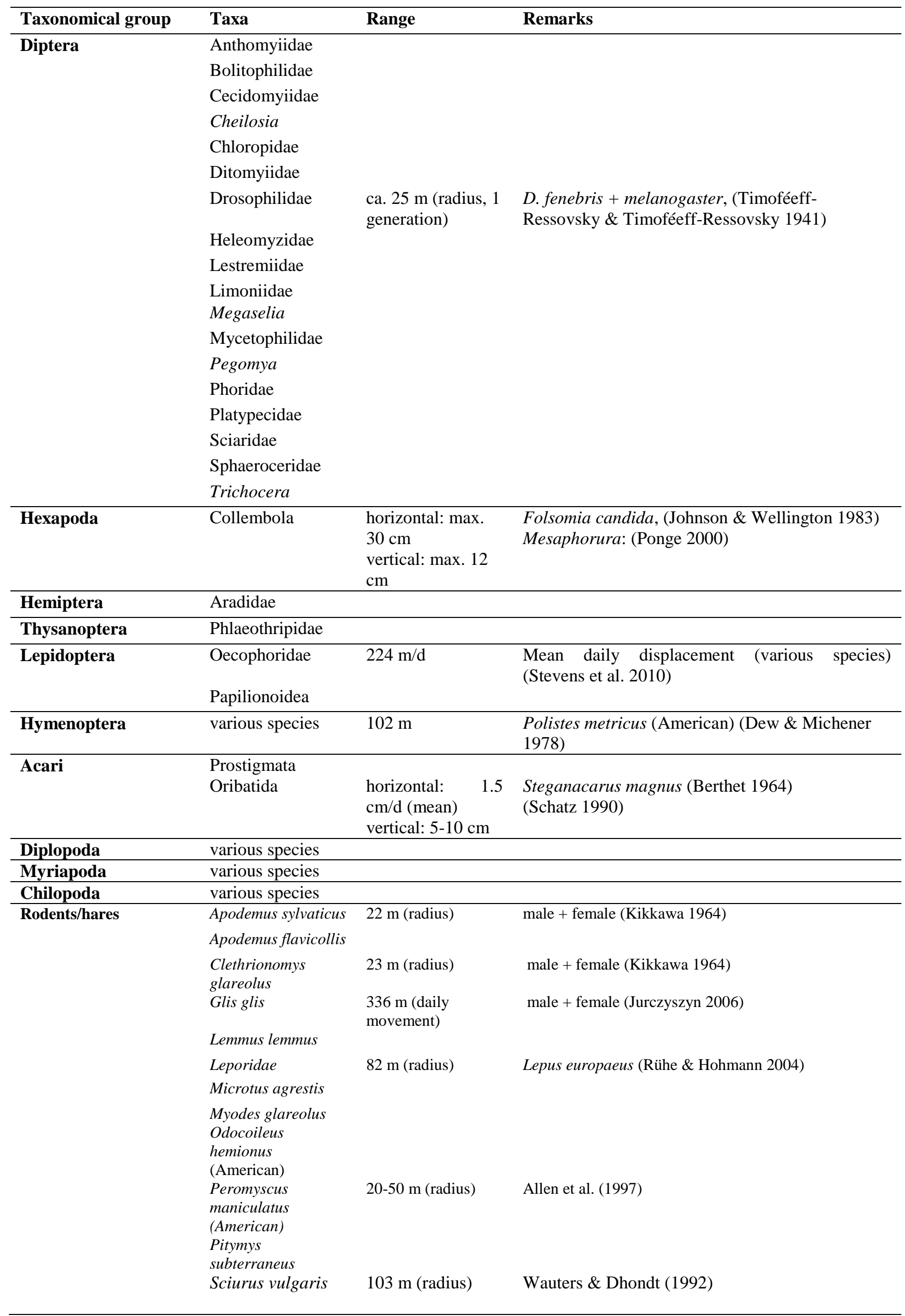




\begin{tabular}{|c|c|c|c|}
\hline Taxonomical group & Taxa & Range & Remarks \\
\hline \multirow[t]{3}{*}{ Shrews } & Sorex alpinus & & \\
\hline & Sorex minutus & & \\
\hline & Sorex araneus & $13 \mathrm{~m}$ (radius) & Nosek et al. (1972) \\
\hline \multirow[t]{4}{*}{ Cervids } & Alces alces & & \\
\hline & $\begin{array}{l}\text { Capreolus } \\
\text { capreolus }\end{array}$ & $164 \mathrm{~m} /$ day & Jeppesen (1990) \\
\hline & Cervus elaphus & $3.5 \mathrm{~km} /$ day & Carranza et al. (1991) \\
\hline & $\begin{array}{l}\text { American cervids } \\
\text { incl. reindeer }\end{array}$ & $14 \mathrm{~km} /$ day & Boertje (1985) \\
\hline \multirow[t]{3}{*}{ Other mammals } & Sus scrofa & $2 \mathrm{~km} /$ day (mean) & Janeau et al. (1995) \\
\hline & Ursus arctos & $7.9 \mathrm{~km} /$ day & Boreal habitat (Gau et al. 2004) \\
\hline & Vulpes vulpes & $7,4 \mathrm{~km} /$ day & Goszczyński (2002) \\
\hline \multirow[t]{2}{*}{ Molluscs } & (Arion lusitanicus) & ca.4 m (radius) & Grimm \& Paill (2001) \\
\hline & $\begin{array}{l}\text { Ariolimax } \\
\text { columbianus } \\
\text { (N. America) } \\
\text { Arion } \\
\text { empiricorum } \\
\text { Arion subfuscus } \\
\text { Deroceras } \\
\text { reticulatum } \\
\text { Limax cinereo- } \\
\text { niger Limax intermedius } \\
\text { Limax maximus } \\
\text { Limax tenellus } \\
\text { Milax marginatus }\end{array}$ & & \\
\hline Earth worms & various species & vertical: ca. $40 \mathrm{~cm}$ & Lumbricus terrestris (Bastardie et al. 2003) \\
\hline Toads & various species & $9.3 \mathrm{~m} / \mathrm{d}$ & Bufo Bufo (Sinsch 1988) \\
\hline Birds & various species & $\begin{array}{l}70 \mathrm{~m} \text { (territory } \\
\text { length) }\end{array}$ & Turdus merula (Greenwood \& Harvey 1978) \\
\hline $\begin{array}{l}\text { Salamander } \\
\text { (Caudata) }\end{array}$ & various species & ca. $10 \mathrm{~m}$ (radius) & S. salamandra (Balogová et al. 2012) \\
\hline Nematoda & $\begin{array}{l}\text { Meloidodera } \\
\text { Aphelenchus }\end{array}$ & $\begin{array}{l}\text { horizontal: } \\
\text { ca. } 2 \mathrm{~cm} / \mathrm{d} \\
\text { vertical: } \max .70 \\
\mathrm{~cm}\end{array}$ & $\begin{array}{l}\text { Trichodorus (Thomas 1981) } \\
\text { Various species: Ou et al. (2005) }\end{array}$ \\
\hline Wind & $\begin{array}{l}\text { Boundary layer } \\
(0.2-10 \mathrm{~cm}) \\
\text { Turbulent } \\
\text { boundary layer } \\
(10 \mathrm{~cm}-10 \mathrm{~m}) \\
\text { Outer layers }(10 \mathrm{~m} \\
\text { - several } \mathrm{km})\end{array}$ & $\begin{array}{l}\text { air still, micro- } \\
\text { eddies may occur } \\
\text { substantial local } \\
\text { eddies } \\
\text { substantial } \\
\text { horizontal and } \\
\text { vertical air } \\
\text { movement }\end{array}$ & $\begin{array}{l}\text { Within forest stands wind speed is } 70-90 \% \text { lower } \\
\text { than in open land (Flemming 1994: 66) }\end{array}$ \\
\hline Mist/clouds & By interception & wind-dependent & \\
\hline Rain & $\begin{array}{l}\text { By interception } \\
\text { and stemflow } \\
\text { In forests by } \\
\text { throughfall } \\
\text { Direct scrubbing, } \\
\text { deposition in open } \\
\text { country }\end{array}$ & $\begin{array}{l}\text { ca. } 30 \mathrm{~cm} \text { (in a } \\
\text { radius of }>3 \mathrm{~m} \text { ) } \\
\text { local } \\
\text { wind-dependent }\end{array}$ & Schwärzel et al. (2012) \\
\hline
\end{tabular}




\subsection{Processing: how spores germinate}

Now that the spore has luckily reached its substrate it needs to germinate in order to fulfil its role, namely to develop a mycelium. Some spores do this readily, as for example in coprophilous fungi, sometimes even when still in the digestive tract, giving them an advantage over potential competitors (Buller 1931).

Coprophilous fungi are typical representatives of xenospore producers. Xenospores are optimised for dispersal, whereas memnospores are the better survivers (Gregory 1966: 187, Carlile et al. 2001). The different characteristics of typical xeno- and memnospores are presented in Table 2.

Table 2 Comparison between memno- and xenospores (based on Cooke \& Whipps 1993: 144)

\begin{tabular}{ll}
\hline Memnospores & Xenospores \\
$\begin{array}{l}\text { Tendency to be large and thick-walled } \\
\text { Tendency to be spherical }\end{array}$ & $\begin{array}{l}\text { Tendency to be small and thin-walled } \\
\text { Tendency to be oblong and showing ornamentation or } \\
\text { protrusions } \\
\text { Survivability relatively low }\end{array}$ \\
$\begin{array}{l}\text { Survivability relatively high } \\
\text { Pronounced dormancy* that leads to delayed germination, } \\
\text { even under favourable conditions. }\end{array}$ & $\begin{array}{l}\text { Dormancy much less common, can readily germinate under } \\
\text { favourable conditions. Fungistasis* under unfavourable } \\
\text { conditions }\end{array}$ \\
$\begin{array}{l}\text { Require specific environmental stimuli, e.g. root exudates } \\
\text { (Grayston et al. 1997) }\end{array}$ & $\begin{array}{l}\text { Breaking fungistasis by improvement of external } \\
\text { conditions, e.g. decreasing microbial stress }\end{array}$ \\
$\begin{array}{l}\text { Typical examples are found in the ectomycorrhizal guild, } \\
\text { e.g. in Lactarius }\end{array}$ & $\begin{array}{l}\text { Typical examples are found in the saprotrophic guild, e.g. } \\
\text { in Mycena }\end{array}$ \\
$\begin{array}{l}\text { Lifestyle predominantly K-selected } \\
\text { Lifestyle predominantly r-selected }\end{array}$
\end{tabular}

Dreaming of a bright future: Dormancy, i.e. delayed germination, is of utmost importance for spore survival. It starts with preventing germination while still within the hymenium, where humidity is high, a mechanism controlled by lack of nutrients and self-inhibition (Carlile et al. 2001: 231) through volatile inhibitory compounds when spore density is high (Sussman \& Halvorson 1966: 275), and probably $\mathrm{CO}_{2}$ in Agaricus bisporus (Rast \& Stäuble 1970).

It continues when spores are dispersed under moist conditions, e.g. by mist or flowing water. Hitting a suitable substrate does not automatically entail immediate germination. It may be too hot or too cold, too dry or dangerous due to temporary microbial attacks (Carlile et al. 2001: 233). The last is especially relevant for spores dispersed by fungivores in taxa that are not dung dwellers, e.g. ectomycorrhizal fungi (Pyare \& Longland 2001, Horton 2006). Ectomycorrhizal fungi may need considerable time to reach host rootlets in the soil, either by e.g. hitching a ride with invertebrates or just by waiting for the relatively slow-growing roots to approach (cf. Brundrett 1991). Spores of agarics may survive for considerable time periods. For example, spores in exsiccates of Psilocybe mutans survived more than nine years (Sussman \& Halvorson 1966: 51). Ectomycorrhizal spores may also stay viable for several years (Bruns et al. 2009, Nara 2009) (Nguyen et al. 2012) and form veritable spore banks together with other fungi (Jumpponen 2003). In this way ectomycorrhizal fungi are able to survive major calamities, such as forest fires and areawide logging (Baar et al. 1999, Barker et al. 2013).

Awakening: All spores of agarics undergo some dormancy or fungistasis, which must be broken for germination to occur. Under natural conditions the right moisture, temperature, inorganic and organic nutrients (Carlile et al. 2001: 235) and a favourable pH (Sussman \& Halvorson 1966: 203ff) are preconditions. Fungistasis stops when microbial stress decreases and nutrient levels increase (Davet 2004: 179). Breaking dormancy is more complicated and the modes of germination are obviously adapted to the specific lifestyles of ecological guilds and even species (Fries 1987). Broadly speaking, release from dormancy needs abiotic and biotic conditions favourable to germination (Van Etten et al. 1983, Cooke \& Whipps 1993: 167) and endogenous enzymes to make the spore wall permeable to external stimuli (Kendrick 1985: 139). 


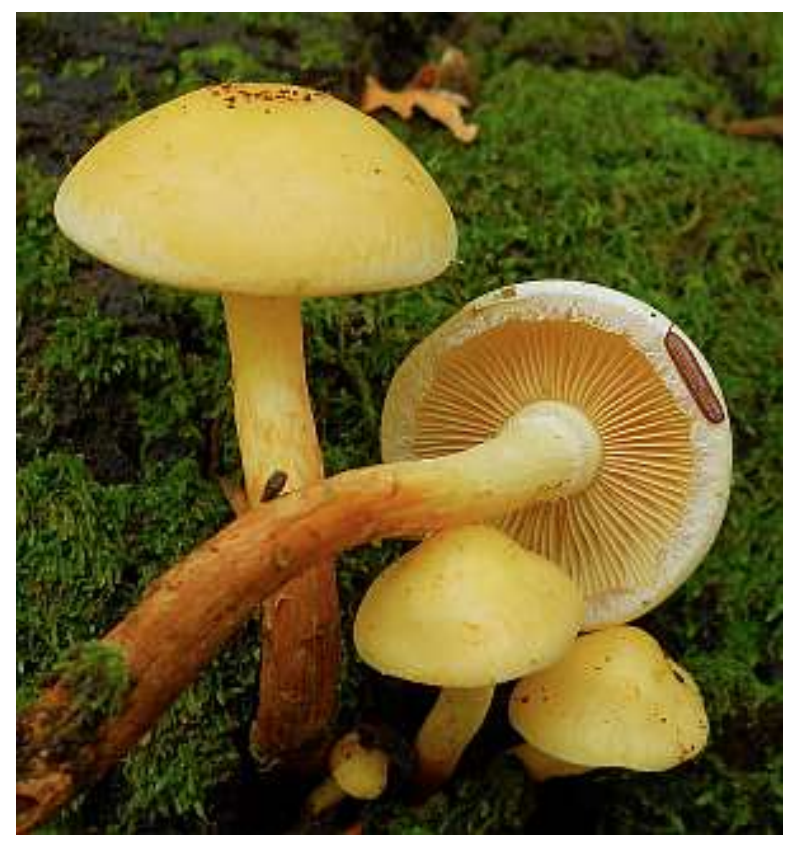

Fig. 19 - Pholiota alnicola (author Hamilton, CC-licensed, http://mushroomobserver.org,)

Most lignicolous and litter inhabiting agarics are the least fussy groups (Fries 1966), though some have special requirements. Coprophilous fungi need passage through animal guts (Hudson 1991: 147). Pleurotus sapidus does not germinate when exposed to white and blue light (daylight!) and germination of Pholiota alnicola Fr. Singer (fig. 19) is improved by prior freezing (Fries 1984). Amyloidity* of some spores may play an important role in dormancy. On the one hand amyloids prevent oxygen entering the spore, slowing down its metabolism (Webster \& Weber 2007: 28). On the other hand the amyloid coat disintegrates with water, thus enabling the spore to germinate (Dodd \& McCracken 1972). Growing mycelium of Agaricus campestris L. ("self-mycelium") stimulates its spores to germinate by volatile substances (Lösel 1964), and also autocatalysis has been observed, i.e. germinating spores trigger germination in neighbouring spores (Fries 1966). In Leccinum the self-mycelium effect is considerable and may even lead to plasmogamy, the sexual merging of germ tubes and hyphae (Fries 1981). Actually, most ectomycorrhizal fungi are quite demanding, they need microbial "company", e.g. a yeast from the genus Rhodotorula and/or selfmycelium and vicinity of host fine roots, which exude stimulating substances (Fries 1984, Brundrett 1991, Cooke \& Whipps 1993: 196). Some Hebeloma, Russula and Lactarius species need to pass through the digestive tracts of slugs (Sussman \& Halvorson 1966: 182). Some overwintering spores need a period of low temperatures in order to germinate (Sussman \& Halvorson 1966: 160ff, Griffin 1996: 385). Under laboratory conditions germination could be triggered by a multitude of treatments with sometimes exotic chemicals, such as organic solvents and acids, gases, phenolic compounds, dyes, sugars, and terpenes. (Sussman \& Halvorson 1966: 168f, Van Etten et al. 1983, Carlile et al. 2001: 236) and fruit body extracts (Fries 1966). But mostly it is difficult to determine the relevance of these experiments for germination under natural conditions, though it is assumed that most of these compounds are emitted by (host) plants (Carlile et al. 2001: 236).

Breakthrough: The very moment a spore is kicked into action it first of all takes up water, mostly recognisable as swelling (Gottlieb 1978: 62), which can be quite dramatic (Griffin 1996: 389). This is a remarkable process, because the spore wall generally constitutes a barrier for water (Griffin 1996: 381f). After having absorbed sufficient moisture one germ tube appears (fig. 20), usually opposite the hilum, but not necessarily (fig. 21). Robinson et al. (1968) observed that when spores of a given species are neighbouring, the germ tube originating from one spore may move away from the other spore (negative autotropism*). In some rare cases more than one germ tube is produced (Wolf \& Wolf 1947: 212). 


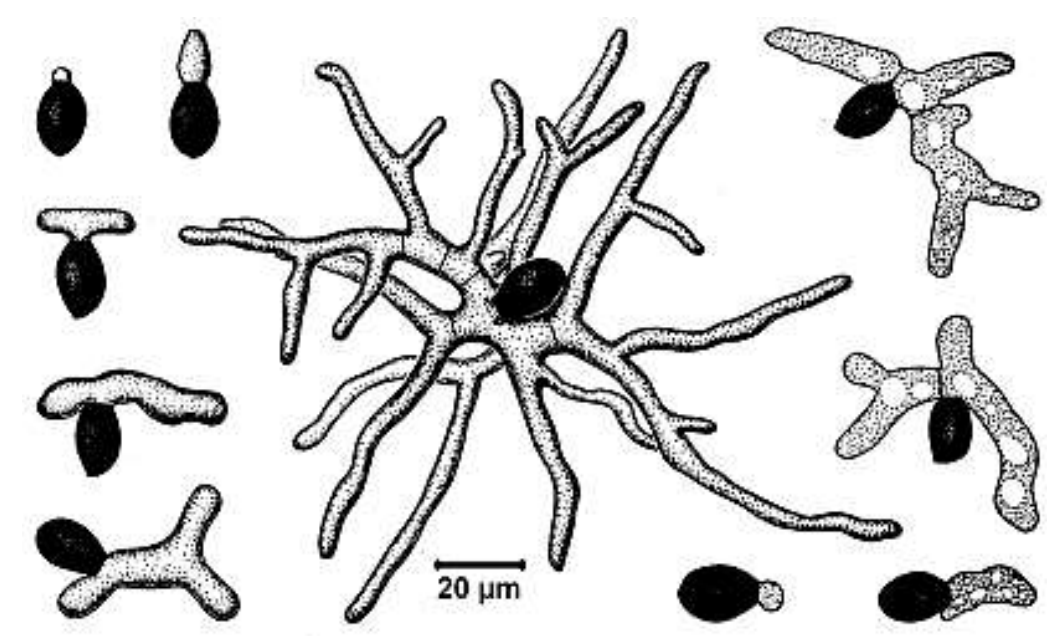

Fig. 20 - Germinating spores of Coprinus sterquilinus (Fr.) Fr. (after Buller 1931: 81)

Particularly in fungi with thick-walled and melanised spores the germ tube pops out of the germ pore, a predetermined breaking spot (Watling 1988, Garnica et al. 2007); see electron microscopical images in Stocks \& Hess (1970). The tube grows towards nutrients, water and volatile compounds emitted by substrates and may avoid oxgen and light (Gow \& Gadd 1995: 7), the latter tropisms acting to keep hyphae within the substrate. The newborn hypha branches and develops septa (fig. 20), and forms a primary, monokaryotic* mycelium. Primary mycelia of compatible mating types eventually fuse to form dikaryotic mycelia (fig. 7). Mating types are part of a breeding system that ensures recombination of different genotypes* (Carlile et al. 2001: 249) by a complicated regime of compatibility factors (Burnett 2003: 135-149).

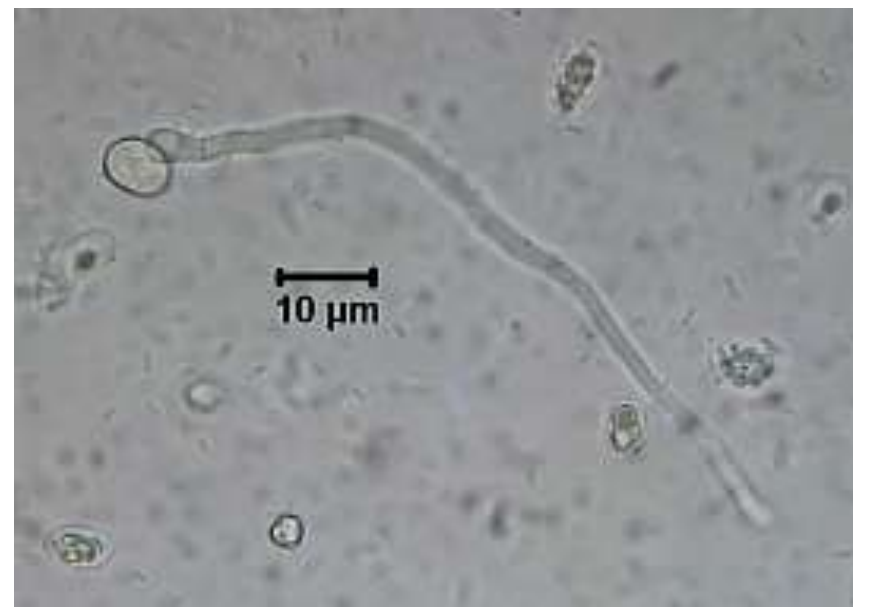

Fig. 21 - Germinating spore of Armillaria borealis Marxm. \& Korhonen (Photo H. Halbwachs)

\subsection{Market forces: spore establishment and competition}

Battling fungi: Fungal species, like other organisms, compete with each other for resources, notably when they colonise similar or identical ecological niches*, to maximise reproductive success (cf. Dybzinski \& Tilman 2009). Competition finally leads to adaptation to other niches (Mayhew 2006: 100f). Dispersal plays a pivotal role in exploiting niches (Perrin 2009), which require morphological and physiological adaptations in fungal spores. These adaptations relate to spore traits with their ecological functions.

Spore size is a fundamental trait, but why does it vary that much? Intuitively one would think that species with large fruit bodies produce large spores, too. Recent statistical investigations have shown that this is the case only to a minor degree (Bässler et al. 2014). There must be more reasons for size variations, most probably relating to dispersal and dormancy (see below). 
Size matters: Large spores travel further than small spores when forcibly launched (ballistospores*) because of a larger momentum (Stolze-Rybczynski et al. 2009, Fischer et al. 2010b). On the other hand small spores are transported by wind over larger distances (Norros et al. 2014) because of their lower settling speed (Falck 1927, Ingold 1965: 7). Hence small spores remain suspended for a longer time and have a greater chance to get "carried away". This effect seems to be eclipsed by high airspeed as it is the case e.g. above canopies (Kuparinen et al. 2007). Small spores harbour less nutrients than larger spores, which may lead to fungistasis (a form of exogenous dormancy, see above and Table 3), an adaptation to temporary nutrient-limited conditions (Davet 2004: 179). Resources for highly specialised species are rare. It is therefore important for these species to boost chances for reaching suitable substrates by maximising their spore production rate, obviously at the expense of size, a classical tradeoff (Nordén et al. 2013).

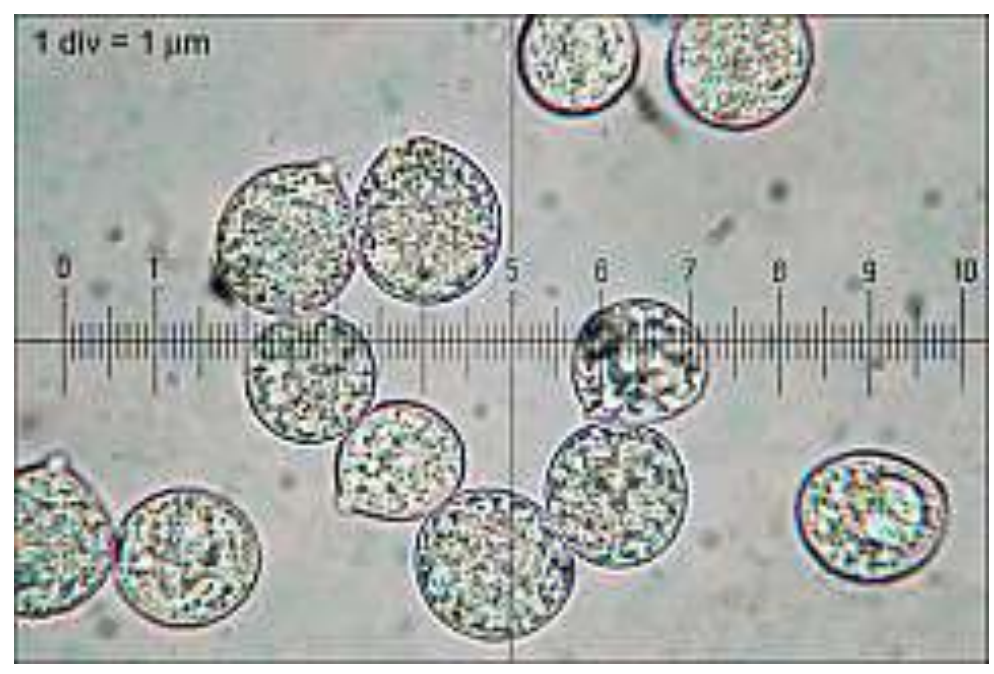

Fig. 22 - Giant spores of Oudemansiella mucida (Schrad.: Fr.) Pat., a tree dwelling mushroom (author Amadej Trnkoczy, CC-licensed, http://mushroomobserver.org,)

Most lignicolous saprotrophs may be better off with large spores (fig. 22), as they are more likely to strike e.g. tree trunks (Ingold 1965: 9-11, Tulloss 2005) and have a high impaction efficiency (Gregory 1973: 93, Hawker \& Madelin 1976: 9f). Also for ectomycorrhizal fungi large spores are likely to be expedient, but for a different reason. They are loaded with considerable amounts of carbon nutrients (Carlile et al. 2001: 233f, Deacon 2005: 185), needed for germination, because only the developed fungus largely obtains carbon from its host (photosynthate, i.e. sugars; Smith \& Read 2008) and cannot extract it from substrates in the soil. For pioneering species that are geared towards reaching new, suitable environments some distance away, small spores may be of advantage, because they may be blown more easily around obstacles (trees!) than large spores (Tulloss 2005). And these spores may have retained some enzymatic power to extract carbon from organic polymers such as cellulose, as known in Lactarius quietus (Courty et al. 2005) and in Suillus granulatus (Cullings et al. 2010).

Shape matters, too: For a given volume, spherical spores expose the least possible surface to a potentially harmful environment and can therefore survive for longer periods (Carlile et al. 2001: 234). Oblong spores with an asymmetrical centre of mass rotate during air dispersal, move sideways (Gregory 1973: 26) and thereby travel farther - at least in non-turbulent and slow moving air - and have improved substrate impaction (Tulloss 2005).

Coats \& arms: Thick-walled spores resist aggressive chemical and microbial agents when passing through digestive tracts of animals (Garnica et al. 2007) (fig. 23). Moreover, they have a higher potential for prolonged dormancy (Hawker \& Madelin 1976, Dix \& Webster 1995: 17). Wall thickness is positively correlated with melanin content (Garnica et al. 2007, Fernandez \& Koide 2013) (see "Coloration" in this section). Thin walls make sense when rapid germination is part of a fungal lifestyle. 


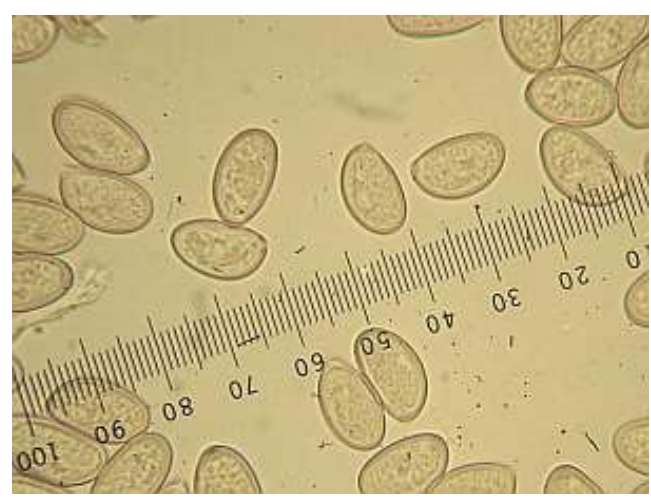

Fig. 23 - Thick-walled spores of Volvopluteus gloiocephalus (DC.) Vizzini, Contu \& Justo (author Ron Pastorino, CC-licensed, http://mushroomobserver.org,)

Decorations: Ornamented spores generally repel water ("Lotus effect") (Wösten \& Wessels 1997, Spori et al. 2008) which may lead to extended dormancy (Gregory 1973: 67), because it takes longer to absorb water needed for germination. Moreover, hydrophoby is a surface property that allows dispersal by mist (Davies 1961, Dörfelt \& Ruske 2010) and soil invertebrates (Ruddick \& Williams 1972).

Ornamentation is said to enhance wind dispersal because of an increased drag (cf. Gube \& Dörfelt 2011). This may not be a general rule, because warts, spines, or ridges do not strongly contribute to drag (Roper et al. 2008). On the other hand, this small effect of ornamentation or irregular shapes as exhibited by some Inocybe and Entoloma species could play an important role when air movement is minimal (cf. Dijksterhuis \& Samson 2007: 66-68). Winged (calyptrate) spores (fig. 24) or spores with distinctly detached outer wall layers (myxosporium), as it is the case with e.g. a number of species of the Coprinopsis and Galerina species (Clémençon et al. 2012: 196f), may in general show significant drag in air drafts and eddies. All this sounds plausible, but needs to be experimentally confirmed.

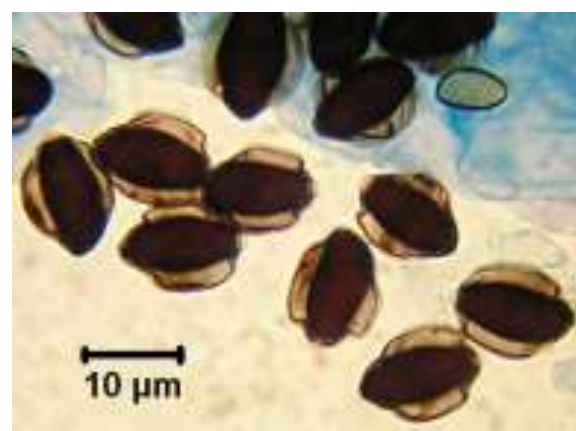

Fig. 24 - Winged spores of Coprinopsis semitalis (P.D. Orton) Redhead, Vilgalys \& Moncalvo (courtesy of Andreas Gminder)

Ornamentation helps in a different way to improve dispersal: ornamented spores cling to (soil) invertebrates such as springtails, beetles or mites, and get transported - possibly in some instances over long distances - into the substrate (Lilleskov \& Bruns 2005). Ornaments also facilitate attachment to substrates (Jennings \& Lysek 1999: 119), i.e. sticking to a substrate after (forceful) landing, e.g. on a log or a soil insect.

Coloration: Pigmentation (melanisation) (fig. 25) may protect against UV irradiation (Durrell 1964, Sussman \& Halvorson 1966: 323, Vellinga 2004), allowing air-dispersed spores to survive long distances and exposure at impact site. Melanins strengthen wall structures (Cooke \& Whipps 1993: 150, 159), provide protection against aggressive substances and microbes (Kuo \& Alexander 1967), lytic enzymes (Bloomfield \& Alexander 1967) and improve drought resistance (Fernandez \& Koide 2013). 
Reddish and yellowish spores may carry sporopollenin polymers derived from carotenoid* pigments in their walls, which also show protective qualities (Ruiz-Herrera 2012: 14).

Hyaline spores with thin walls germinate quickly, which is useful in habitats with short growing season, e.g. in arctic biomes* (Cline \& Zak 2013).

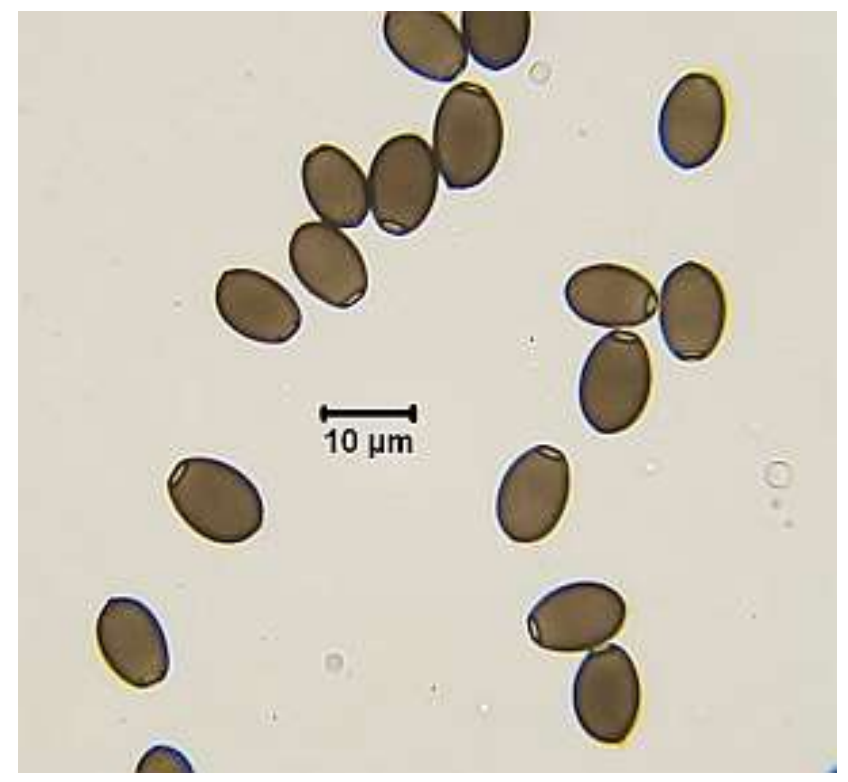

Fig. 25 - Melanised spores of Coprinus comatus with germ pores (O.F. Müll.) Pers. (courtesy of Gernot Friebes)

Germ pores only occur in thick-walled spores. Thick walls are a well-known adaptation for the survival of spores in digestive tracts of animals (Garnica et al. 2007). Germ pores are primarily an adaptation to survive harsh conditions in mammalian digestive systems, yet allowing quick germination after excretion (Boddy et al. 1988). This mainly applies to saprotrophic taxa, especially coprophilous fungi (fig. 23). Most ectomycorrhizal fungi do not have germ pores (Halbwachs et al. 2014), only very few Inocybe (pioneer?) species exhibit indistinct pores (Knudsen \& Vesterholt 2012: 981) which may point at animals as preferred vectors.

Solving the riddle: At the beginning of this review we presented an image of conspicuous spores (fig. 1). They belong to Inocybe petchii Boedijn (an ectomycorrhizal species from the tropics), are thick-walled, melanised and have eye-catching spikes. In tropical forests suitable host trees are rare, so that ectomycorrhizal spores need to go around obstacles and travel long distances. The ornamentation may facilitate transport over long distances in the fur of mammals and in final dispersal to the roots by animals such as arthropods.

\section{Ways of living: saprotrophic and ectomycorrhizal lifestyles}

Saprotrophic fungi have a lifestyle that is typically and distinctly different from the more residential ectomycorrhizal guild, which relies on the renewable energy of host plants, produced by photosynthesis. The ecological differences between the guilds are to a certain extent mirrored by their spores. A comparison between the peculiarities of both guilds and corresponding spore traits shows that foraging strategies can be connected to reproductive patterns.

Most ectomycorrhizal fruit bodies are relatively stocky and fleshy. Therefore exposure of the hymenium to air currents is often limited. This is possibly one reason why ectomycorrhizal fungi need also be dispersed by aboveground animals by ingestion and excretion. Finally the spores need to get into the rhizosphere, probably often by soil invertebrates as described above. This may be the reason why ectomycorrhizal spores are more frequently ornamented than saprotrophic ones (Halbwachs et al. 2014). But some spores may also reach deeper soil layers by becoming washed down by precipitation (Gregory 1945, Ingold 1971: 88) 
Saprotrophic agarics with a ruderal strategy obviously depend more on distant dispersal and quick germination success. For them relatively small, oblong and thin-walled spores and slender fruit bodies are more expedient, except for the specialised dung dwellers. Those in particular obviously need germ pores for quick germination. About $20 \%$ of ectomycorrhizal taxa show a ruderal behaviour. These pioneer include species of e.g. Hebeloma, Inocybe and Laccaria (Guidot et al. 2001, Cripps 2004, Nara 2009) (fig. 26), of which ca. 50\% show thick spore walls compared with ca. $1 \%$ in other ectomycorrhizal taxa described in (Knudsen \& Vesterholt 2012). Ca. 95\% of these pioneers have pigmented spores walls, compared to $46 \%$ in other taxa (data not shown). Hence, thick and coloured spore walls appear to be an advantage for pioneer ectomycorrhizal fungi. This probably reflects the hazards pioneer ectomycorrhizal fungi have to cope with, when colonising new territory: exposure to UV-radiation during air dispersal over open land, microbial stress during zoochory*, and delays in germination ("sit and wait" strategy).

This all appears to be quite plausible. And indeed, spore wall thickness and ornamentation patterns seem to be the result of selective forces, as a phylogenetic informed analysis showed (Halbwachs et al. 2014). In contrast, size and shape patterns are not that clear-cut: even though ectomycorrhizal species show statistically significantly larger and more spherical spores than saprotrophic terricolous and lignicolous species, when correcting for phylogeny*, the differences vanish (Bässler et al. 2014).

In other words, size and shape are lineage-specific (cf. Meerts 1999) and deeply rooted in the evolutionary tree. Which also means that the size-shape syndrome in ectomycorrhizal spores is not a result of gradual adaptation towards prolonged dormany and longevity. But still, taking into account the fact that at least the taxa of temperate and boreal habitats do not include genera that contain ectomycorrhizal and saprotrophic species (or only very few, as in Amanita: R.E. Tulloss, pers. comm.) may be of evolutionary significance. It could well be that predominantly spores of those taxa that show the size-shape syndrome may have developed into ectomycorrhizal species (preadaptation, exaptation; cf. Levin 2009: 97-100), something which eventually could be clarified e.g. by using differentiated phylogenetic trees that allow statistical analyses for tracing the sequence of trait evolution.

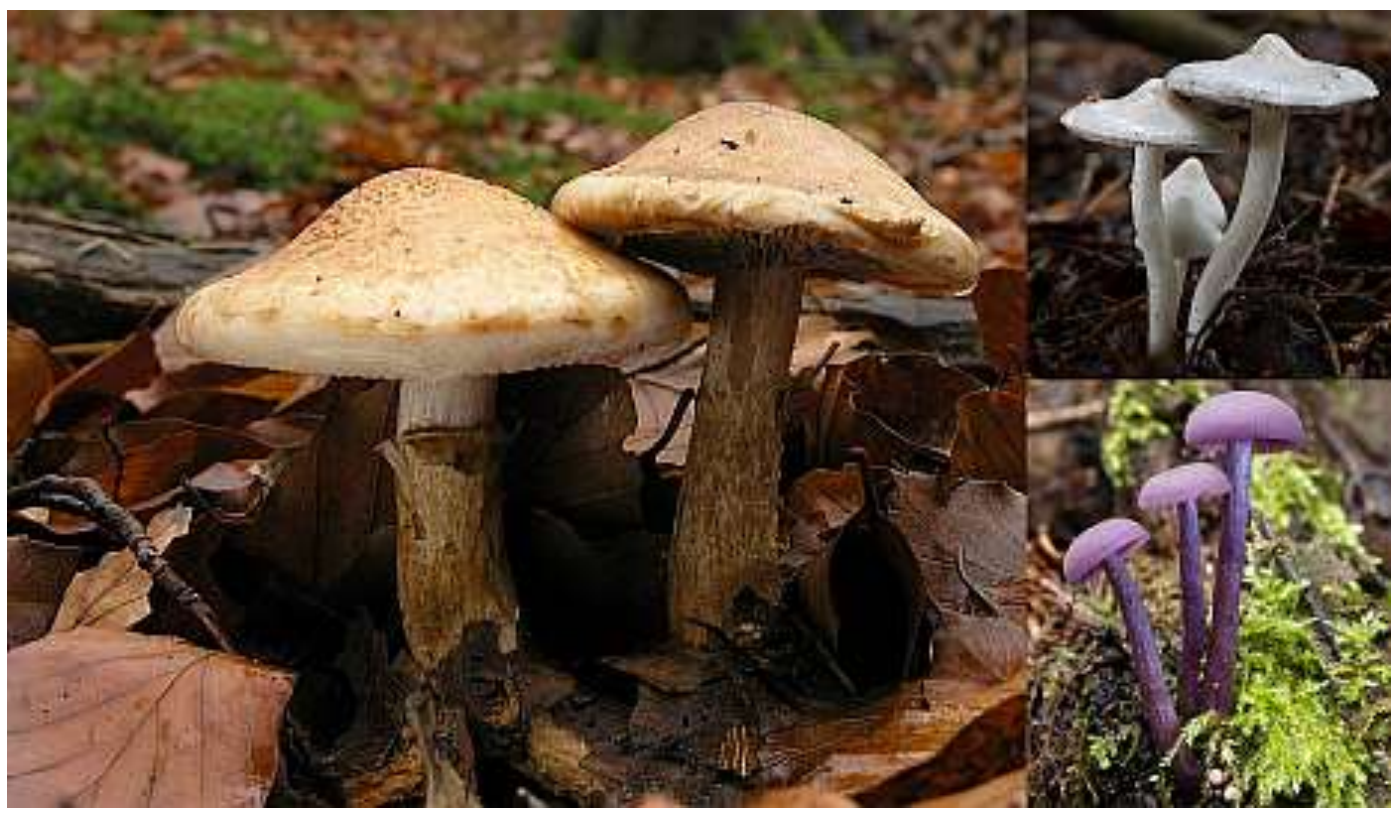

Fig. 26 - Hebeloma radicosum (Bull.) Ricken (left), Inocybe geophylla (Bull.) P. Kumm. (top right) and Laccaria amethystina Cooke (bottom right). Images courtesy of Georg Müller, http://www.pilzepilze.de. 


\section{Conclusion: the gist of it}

Spores are pivotal for agarics to distribute and to maintain genetic flexibility, i.e. adaptability. The variability of spore size, shape, wall thickness, ornamentation, pigmentation and presence of gem pores implies a connection to the lifecycle and lifestyle of agarics. It seems obvious that

- variability in spores predominantly serves ecological functions,

- spore traits must be in line with requirements during a fungal lifecycle,

- mutualist and saprotrophic guilds show different trait sets, perhaps due to their different nutritional behaviours,

- dispersal must rely on a broad range of vectors, and that

- animals may play a crucial role in dispersing ectomycorrhizal spores.

It appears that research about the ecological role of basidiospores is almost stalling. We therefore call for more studies in this field, to follow up the considerable ground work of the pioneers and later workers in spore research. Research is e.g. needed to elucidate and quantify transport mechanisms of spores to suitable soil layers, particularly for the ectomycorrhizal guild. For this an experimental approach with mesocosms could be a promising path.

To elucidate the role of basidiospores during the transition from a saprotrophic to a mutualistic lifestyle we propose to phylogenetically analyse more broad data sets (trait reconstruction), possibly across other phyla and from different biomes. Furthermore we suggest identifying genetic markers for spore size and shape along phylogentic trees, a truly huge challenge.

Table 3 Glossary, mainly based on Kirk et al. (2011) and wikipedia.org and similar Internet resources

\section{Adaxial \\ Agaricomycetidae \\ Amyloidity}

\section{Anastomosis}

Autotropism

Ballistospores

\section{Biome}

Carotenes

Dikaryotic

Dormancy

\section{Fungistasis}

\section{Genotypes \\ Geotropic \\ Haploid \\ Heterospory \\ Lipids \\ Meiospores \\ Melanins}

the side of a spore that faces the axis of the basidium

include the Agaricales, Atheliales and Boletales

and pseudoamyloidity are important features of spore and hyphal walls for the identification of species. It is a reaction of starchy substances with iodine leading to a brownish to blue-black colour.

happens when two germ tubes or hyphae fuse

is positive, when germ tubes or hyphae grow towards each other, eventually leading to anastomosis*. Negative autotropism is the contrary, to avoid e.g. competition for nutrients.

are actively and forcibly expelled from basidia using a mechanism based on the surface tension of water (see above).

another term for ecosystem.

polymeric yellowish/reddish pigments, synthesised by plants

are cells (spores, hyphae) with two nuclei

ability to spend considerable time, in some cases years, in a resting state but to remain viable until conditions are favourable for germination. Dormancy can be induced by external factors (exogenous dormancy), e.g. temperature. Endogenous (or constitutive) dormancy depends on structural or metabolic features of the spore, that need special conditions for germination (Carlile et al. 2001: 231), e.g. the presence of certain microorganisms such as Rhodotorula (Fries 1987).

inhibition of germination and may be induced by microorganisms in the substrate, probably by exhausting nutrients (Carlile et al. 2001: 233) and by alteration of soil chemistry $(\mathrm{pH})$ or simply by lack of water (Henis et al. 1987). As a rule it can be said that the smaller the spore, the more liable it is to fungistasis (Davet 2004: 174, 179).

are genetically identical members of a clone (genet)

are organisms that grow towards (positive geotropism) or away from (negative geotropism) the gravitational pull of, in our case, the earth.

are nuclei with a single set of chromosomes, in contrast to diploidity (two chromosome sets)

occurs in some species, which show two or more spore size clusters

are fatty, oily and waxy organic compounds

contain one or more haploid* nuclei, the product of meiosis (reduction division)

polymers of oxidised tyrosine, an amino acid 


\begin{tabular}{|c|c|}
\hline Monokaryotic & are cells (spores, hyphae) with one nucleus \\
\hline Niches & $\begin{array}{l}\text { are determined by environmental conditions, including competing organisms, and the } \\
\text { resources that define the requirements of an individual or a species to practise its } \\
\text { lifestyle }\end{array}$ \\
\hline Paraphyses & sterile, mostly hyphal filaments in a hymenium \\
\hline Peridium & membranous rind of a fruit body, particularly of Gastromycetes \\
\hline Phylogeny & describes genealogical relationships of organisms as part of the "tree of life" \\
\hline Pileipellis & cortex of the cap \\
\hline Plage & smooth spot above the hilar appendage \\
\hline Revolution ellipsoid & elongated sphere, similar to the shape of a rugby ball \\
\hline Riparian forest & forest bordering rivers, lakes etc. \\
\hline Setae & hair-like, generally thick-walled, sterile hyphal ends \\
\hline Stereotaxis & or thigmotaxis is the movement of an organism in response to contact with a solid body \\
\hline Vector & is an organism that carries and disperses propagules of a different species \\
\hline Zoochory & dispersal by animals \\
\hline
\end{tabular}

Table 4 Additional literature on dispersal vectors

\begin{tabular}{ll}
\hline $\begin{array}{l}\text { Grassland } \\
\text { invertebrates }\end{array}$ & Frenzel G. 1936 - Untersuchungen über die Tierwelt des Wiesenbodens. Gustav Fischer, \\
Coleoptera & Jena. \\
Siptera & Scheerpeltz O, Höfler K. 1948 - Käfer und Pilze. Verlag für Jugend und Volk, Wien. \\
& Boddy L, Jones TH. 2008 - Interactions between basidiomycota and invertebrates. In: \\
& 155-179. \\
& Hammond P, Lawrence J. 1989- Appendix: Mycophagy in insects: a summary. In: Wilding \\
& N, Collins NM, Hammond PM, Webber JF. Insect-fungus interactions. - Academic Press, \\
& London, 275-324. \\
Hemiptera, & Wilding N, Collins NM, Hammond PM, Webber JF. 1989 - British Mycological Society - \\
Hymenoptera, & Royal Entomological Society of London, Symposium: Insect-fungus interactions. \\
Lepidoptera, & Academic Press.
\end{tabular}

Blaschke H, Bäumler W. 1989 - Mycophagy and spore dispersal by small mammals in Bavarian forests. Forest Ecology and Management 26(4), 237-245.

Cervids Fielitz U, Albers U. 1996 - Nahrungsspektrum von Rehen aus dem Bayerischen Wald. Zeitschrift für Jagdwissenschaft 42(3), 195-202.

Jensen PV. 1968 - Food selection of the Danish Red Deer (Cervus elaphus L.) as determined by examination of the rumen content. Vildtbiologisk Station.

Latham J, Staines B, Gorman M. 1999 - Comparative feeding ecology of red (Cervus elaphus) and roe deer (Capreolus capreolus) in Scottish plantation forests. Journal of Zoology 247(3), 409-418.

Launchbaugh KL, Urness PJ. 1992 - Mushroom consumption (mycophagy) by North American cervids. Western North American Naturalist 52(4), 321-327.

Other mammals Luoma DL, Trappe JM, Claridge AW, Jacobs KM, Cazares E. 2003 - Relationships among fungi and small mammals in forested ecosystems. In: Zable C, Anthony R. In Mammal community dynamics: management and conservation in the coniferous forests of Western North America. Cambridge University Press, Cambridge. -, 343-373.

Schley L, Roper TJ. 2003 - Diet of wild boar Sus scrofa in Western Europe, with particular reference to consumption of agricultural crops. Mammal Review 33(1), 43-56.

Molluscs

Speiser B. 2001 - Food and Feeding Behaviour. The biology of terrestrial molluscs. CABI, 259-288.

\section{Acknowledgement}

Our sincere thanks go to Heino Lepp (Honorary Associate, Australian National Herbarium) for his linguistic revision and other useful suggestions, which greatly improved the manuscript.

\section{References}

Allen MF, Klironomos JN, Harney S. 1997 - The Epidemiology of Mycorrhizal Fungal Infection During Succession. In: Carroll G, Tudzynski P. Plant Relationships Part B. - Springer Berlin Heidelberg, 169-183. 
Ashkannejhad S, Horton TR. 2006 - Ectomycorrhizal ecology under primary succession on coastal sand dunes: interactions involving Pinus contorta, suilloid fungi and deer. New Phytologist 169(2), 345-354.

Baar J, Horton TR, Kretzer A, Bruns TD. 1999 - Mycorrhizal colonization of Pinus muricata from resistant propagules after a stand-replacing wildfire. New Phytologist 143(2), 409-418.

Balogová M, Uhrin M, Kaňuk J, Kal'avský J. 2012 - Salamandra salamandra in Slovakia, distribution and habitat. Folia Veterinaria 56(4), 3-6.

Barker J, Simard S, Jones M, Durall DM. 2013 - Ectomycorrhizal fungal community assembly on regenerating Douglas-fir after wildfire and clearcut harvesting. Oecologia 172(4), 11791189.

Bartnicki-Garcia S. 1968 - Cell wall chemistry, morphogenesis, and taxonomy of fungi. Annual Reviews in Microbiology 22(1), 87-108.

Bässler C, Heilmann-Clausen J, Karasch P, Brandl R, Halbwachs H. 2014 - Ectomycorrhizal fungi have larger fruit bodies than saprotrophic fungi. Fungal Ecology 10.1016/j.funeco.2014.06.005.

Bastardie F, Capowiez Y, Cluzeau D. 2003 - Burrowing behaviour of radio-labelled earthworms revealed by analysis of 3D-trajectories in artificial soil cores: The 7th international symposium on earthworm ecology. Cardiff. Wales. 2002. Pedobiologia 47(5), 554-559.

Bauch R. 1926 - Untersuchungen über zweisporige Hymenomyceten I. Haploide Parthenogenesis bei Camarophyllus virgineus. Zeitschrift für Botanik XVIII, 337-387.

Bauer H, Schueller E, Weinke G, Berger A, Hitzenberger R, Marr IL, Puxbaum H. 2008 Significant contributions of fungal spores to the organic carbon and to the aerosol mass balance of the urban atmospheric aerosol. Atmospheric Environment 42(22), 5542-5549.

Berthet P. 1964 - Field study of the mobility of Oribatei (Acari), using radioactive tagging. The Journal of Animal Ecology 33, 443-449.

Bloomfield B, Alexander M. 1967 - Melanins and resistance of fungi to lysis. Journal of Bacteriology 93(4), 1276-1280.

Boddy L, Watling R, Lyon A, 1988. Fungi and ecological disturbance, Cambridge Univ Press, 1188.

Boertje RD. 1985 - Seasonal activity of the Denali caribou herd, Alaska. Rangifer 5(2), 32-42.

Boertmann D. 2010 - The Genus Hygrocybe. Svampetryk, Tilst.

Bonn S, Poschlod P. 1998 - Ausbreitungsbiologie der Pflanzen Mitteleuropas.: Grundlagen und kulturhistorischen Aspekte. Quelle \& Meyer Verlag.

Brefeld O. 1877 - Botanische Untersuchungen uber Schimmelpilze, vol. III. Leipzig.

Brundrett MC. 1991 - Mycorrhizas in natural ecosystems. In: Begon M, Fitter AH, Macfadyen A. Advances in Ecological Research 1991 Volume 21. - Academic Press, London, 171-313.

Bruns TD, Peay KG, Boynton PJ, Grubisha LC, Hynson NA, Nguyen NH, Rosenstock NP. 2009 Inoculum potential of Rhizopogon spores increases with time over the first 4 yr of a 99-yr spore burial experiment. New Phytologist 181(2), 463-470.

Buller AHR. 1909 - Researches on Fungi. Longmans, Green and Co., London.

Buller AHR. 1922 - Researches on Fungi volume II. Longmans, Green and Co., London.

Buller AHR. 1924 - Researches on Fungi volume III. Longmans, Green and Co., London.

Buller AHR. 1931 - Researches on Fungi volume IV. Longmans, Green and Co., London.

Burch M, Levetin E. 2002 - Effects of meteorological conditions on spore plumes. International journal of biometeorology 46(3), 107-117.

Burchill RT. 1966 - Air-dispersal of fungal spores with particular reference to apple scab (Venturia inaequalis (Cooke) Winter). In: Madelin M. The fungus spore. - Butterworths, London, $135-141$.

Burnett JH. 2003 - Fungal population genetics and species. Oxford University Press, Incorporated.

Carlile M, Watkinson S, Gooday G. 2001 - The Fungi. Academic Press, New York.

Carranza J, Hidalgo de Trucios SJ, Medina R, Valencia J, Delgado J. 1991 - Space use by red deer 
in a Mediterranean ecosystem as determined by radio-tracking. Applied Animal Behaviour Science 30(3), 363-371.

Claridge A, Trappe J, 2005 - Sporocarp mycophagy: nutritional, behavioral, evolutionary, and physiological aspects. The fungal community - it's organization and role in the ecosystem. Dighton J, White JF, Oudemans P. Taylor \& Francis, Boca raton, 599-611.

Clémençon H, Emmett V, Emmett EE. 2012 - Cytology and Plectology of the Hymenomycetes. J. Cramer.

Cline LC, Zak DR. 2013 - Dispersal limitation structures fungal community assembly in a long-term glacial chronosequence. Environmental microbiology.

Cooke RC, Whipps JM. 1993 - Ecophysiology of fungi. Blackwell Scientific Publications.

Corner E. 1947 - Variation in the size and shape of spores, basidia and cystidia in Basidiomycetes. New Phytologist 46(2), 195-228.

Corner E. 1948 - Studies in the basidium. I. The ampoule effect, with a note on nomenclature. New Phytologist 47(1), 22-51.

Courty PE, Pritsch K, Schloter M, Hartmann A, Garbaye J. 2005 - Activity profiling of ectomycorrhiza communities in two forest soils using multiple enzymatic tests. New Phytologist 167(1), 309-319.

Cripps C. 2004 - Ectomycorrhizal fungi above and below ground in a small, isolated aspen stand: a simple system reveals fungal fruiting strategies and an edge effect. In: Cripps C. Fungi in forest ecosystems: systematics, diversity, and ecology. - The New York Botanical Garden Press, New York, 249-265.

Crockford RH, Richardson DP. 2000 - Partitioning of rainfall into throughfall, stemflow and interception: effect of forest type, ground cover and climate. Hydrological processes 14(1617), 2903-2920.

Cullings K, Ishkhanova G, Ishkhanov G, Henson J. 2010 - Induction of saprophytic behavior in the ectomycorrhizal fungus Suillus granulatus by litter addition in a Pinus contorta (Lodgepole pine) stand in Yellowstone. Soil Biology and Biochemistry 42(7), 1176-1178.

Dahlberg KR, Etten J. 1982 - Physiology and biochemistry of fungal sporulation. Annual review of phytopathology 20(1), 281-301.

Davet P. 2004 - Microbial Ecology of the Soil and Plant Growth. Science Publishers, Inc., Enfield.

Davies R. 1961 - Wettability and the capture, carriage and deposition of particles by raindrops. Nature 191, 616-617.

Deacon J. 2005 - Fungal Biology. Blackwell Publishers, Malden, MA.

Deering R, Dong F, Rambo D, Money NP. 2001 - Airflow patterns around mushrooms and their relationship to spore dispersal. Mycologia 93(4), 732-736.

Després VR, Huffman JA, Burrows SM, Hoose C, Safatov AS, Buryak G, Fröhlich-Nowoisky J, Elbert W, Andreae MO, Pöschl U. 2012 - Primary biological aerosol particles in the atmosphere: a review. Tellus B 64.

Dew HE, Michener CD. 1978 - Foraging flights of two species of Polistes wasps (Hymenoptera: Vespidae). Journal of the Kansas Entomological Society, 380-385.

Dijksterhuis J, Samson RA. 2007 - Food Mycology: A Multifaceted Approach to Fungi and Food. Taylor \& Francis.

Dix N, Webster J. 1995 - Fungal Ecology. Chapman and Hall, London.

Dodd J, McCracken D. 1972 - Starch in fungi. Its molecular structure in three genera and an hypothesis concerning its physiological role. Mycologia 64(6), 1341-1343.

Dörfelt H, Jetschke G. 2001 - Wörterbuch der Mycologie. Spektrum Akademischer Verlag.

Dörfelt H, Ruske E. 2010 - Hydrophobie von Basidiosporen als Merkmal der Gasteromycetation. Zeitschrift für Mykologie 76(2), 153-170.

Dressaire E, Santoso J, Yamada L, Roper M. 2013 - Control of fluidic environments by mushrooms. Bulletin of the American Physical Society 58. 
Dring DM. 1973 - Gasteromycetes. In: Ainsworth GC, Sparrow FK, A.S. S. The fungi, an advanced treatise IVb: A taxonomic review with keys. - Academic Press, New York, 451478.

Durrell LW. 1964 - The composition and structure of walls of dark fungus spores. Mycopathologia 23(4), 339-345.

Dybzinski R, Tilman D. 2009 - Competition and Coexistence in Plant Communities. In: S.A. L. The Princeton Guide to Ecology -Princeton University Press, 186-195.

Elliott T. 1977 - Basidiospore Numbers in Agaricus bisporus (Lange) Imbach. Journal of Bacteriology 129(1), 525.

Erb B, Matheis W. 1983 - Pilzmikroskopie: Präparation und Untersuchung von Pilzen. Franckh'sche Verlagshandlung.

Falck R. 1927 - Über die Größen, Fallgeschwindigkeiten und Schwebewerte der Pilzsporen und ihre Gruppierung mit Bezug auf die zu ihrer Verbreitung nötigen TemperaturströmungsGeschwindigkeiten. Berichte der Deutschen Botanischen Gesellschaft XLV(5), 262-281.

Fernandez CW, Koide RT. 2013 - The function of melanin in the ectomycorrhizal fungus Cenococcum geophilum under water stress. Fungal Ecology 6(6), 479-486.

Fischer MW, Money NP. 2010 - Why mushrooms form gills: efficiency of the lamellate morphology. Fungal Biology 114(1), 57-63.

Fischer MW, Stolze-Rybczynski JL, Cui Y, Money NP. 2010a - How far and how fast can mushroom spores fly? Physical limits on ballistospore size and discharge distance in the Basidiomycota. Fungal Biology 114(8), 669-675.

Fischer MW, Stolze-Rybczynski JL, Davis DJ, Cui Y, Money NP. 2010b - Solving the aerodynamics of fungal flight: how air viscosity slows spore motion. Fungal Biology 114(11), 943-948.

Fleming PA, Anderson H, Prendergast AS, Bretz MR, Valentine LE, Hardy GE. 2014 - Is the loss of Australian digging mammals contributing to a deterioration in ecosystem function? Mammal Review 44(2), 94-108.

Flemming G. 1994 - Wald Wetter Klima. Deutscher Landwirtschaftsverlag, Berlin.

Fogel R, Trappe JM. 1978 - Fungus consumption (mycophagy) by small animals. Northwest Science 52(1), 1-31.

Frenzel G. 1936 - Untersuchungen über die Tierwelt des Wiesenbodens. Gustav Fischer, Jena.

Fries N. 1966 - Chemical factors in the germination of spores of Basidiomycetes. In: Madelin M. The fungus spore. - Butterworths, London, 189-199.

Fries N. 1981 - Recognition reactions between basidiospores and hyphae in Leccinum. Transactions of the British Mycological Society 77(1), 9-14.

Fries N. 1984 - Spore germination in the higher Basidiomycetes. Proceedings: Plant Sciences 93(3), 205-222.

Fries N. 1987 - Ecological and evolutionary aspects of spore germination in the higher basidiomycetes. Trans. Br. Mycol. Soc. 88(1), 1-7.

Fröhlich-Nowoisky J, Pickersgill DA, Després VR, Pöschl U. 2009 - High diversity of fungi in air particulate matter. Proceedings of the National Academy of Sciences 106(31), 1281412819.

Frömming E. 1940 - Über das Verhalten unserer Nacktschnecken gegenüber den Blätter- und Löcherpilzen. Angewandte Botanik, Zeitschrift der Vereinigung für angewandte Botanik 22(2), 157-167.

Fukiharu T, Shimizu K, Li R, Raut JK, Yamakoshi S, Horie Y, Kinjo N. 2012 - Coprinopsis novorugosobispora sp. nov., an agaric ammonia fungus from Beijing, China. Mycoscience.

Galante TE, Horton TR, Swaney DP. $2011-95 \%$ of basidiospores fall within $1 \mathrm{~m}$ of the cap: a field-and modeling-based study. Mycologia 103(6), 1175-1183.

Gange A, Bower E. 1997 - Interactions between insects and mycorrhizal fungi. In: Gange AC, Brown VK. Multitrophic interactions in terrestrial systems. - Cambridge University Press, $115-132$. 
Garnica S, Weiss M, Walther G, Oberwinkler F. 2007 - Reconstructing the evolution of agarics from nuclear gene sequences and basidiospore ultrastructure. Mycological Research 111(9), 1019-1029.

Gau RJ, McLoughlin PD, Case R, Cluff HD, Mulders R, Messier F. 2004 - Movements of subadult male grizzly bears, Ursus arctos, in the central Canadian arctic. The Canadian FieldNaturalist 118(2), 239-242.

Geml J, Timling I, Robinson CH, Lennon N, Nusbaum HC, Brochmann C, Noordeloos ME, Taylor DL. 2012 - An arctic community of symbiotic fungi assembled by long-distance dispersers: phylogenetic diversity of ectomycorrhizal basidiomycetes in Svalbard based on soil and sporocarp DNA. Journal of Biogeography 39(1), 74-88.

Girard V, Schmidt AR, Struwe S, Perrichot V, Breton G, Néraudeau D. 2009 - Taphonomy and palaeoecology of mid-Cretaceous amber-preserved microorganisms from southwestern France. Geodiversitas 31(1), 153-162.

Goszczyński J. 2002 - Home ranges in red fox: territoriality diminishes with increasing area. Acta Theriologica 47(1), 103-114.

Gottlieb D. 1978 - The germination of fungus spores. Meadowfield Press Ltd.

Gow N, Morris B. 1995 - The electric fungus. Transactions and Proceedings of the Botanical Society of Edinburgh and Botanical Society of Edinburgh Transactions 47(2), 263-277.

Gow NAR, Gadd GM. 1995 - The growing fungus. Springer.

Grayston SJ, Vaughan D, Jones D. 1997 - Rhizosphere carbon flow in trees, in comparison with annual plants: the importance of root exudation and its impact on microbial activity and nutrient availability. Applied Soil Ecology 5(1), 29-56.

Greenwood PJ, Harvey PH. 1978 - Foraging and territory utilization of blackbirds (Turdus merula) and song thrushes (Turdus philomelos). Animal Behaviour 26, 1222-1236.

Gregory P. 1945 - The dispersion of air-borne spores. Transactions of the British Mycological Society 28(1), 26-72.

Gregory P. 1966 - The fungus spore: what it is and what it does. In: Madelin M. The fungus spore. - Butterworths, London, 1-13.

Gregory PH. 1957 - Electrostatic Charges on Spores of Fungi in Air. Nature 180(4581), 330-330.

Gregory PH. 1973 - Microbiology of the Atmosphere, 2nd edition. John Wiley \& Sons, New York.

Griffin DH. 1996 - Fungal physiology. John Wiley and Sons, New York.

Grimm B, Paill W. 2001 - Spatial distribution and home-range of the pest slug Arion lusitanicus (Mollusca: Pulmonata). Acta Oecologica 22(4), 219-227.

Gube M, Dörfelt H. 2011 - Gasteromycetation in Agaricaceae sl (Basidiomycota): Morphological and ecological implementations. Feddes Repertorium 122(5-6), 367-390.

Guidot A, Debaud JC, Marmeisse R. 2001 - Correspondence between genet diversity and spatial distribution of above- and below-ground populations of the ectomycorrhizal fungus Hebeloma cylindrosporum. Molecular Ecology 10(5), 1121-1131.

Haard R, Kramer C. 1970 - Periodicity of spore discharge in the Hymenomycetes. Mycologia, $1145-1169$.

Halbwachs H, Bässler C. 2012 - Hängt der Wachstumsverlauf der Fruchtkörper der Ektomykorrhizapilze vom Wirtsverhalten ab? Messmethode und erste Ergebnisse. Zeitschrift für Mykologie 78(2), 211-223.

Halbwachs H, Brandl R, Bässler C. 2014 - Spore wall traits of ectomycorrhizal and saprotrophic agarics may mirror their distinct lifestyles. Fungal ecology, http://dx.doi.org/10.1016/j.funeco.2014.1010.1003.

Hanski I. 1989 - Fungivory: fungi, insects and ecology. In: Wilding N, Collins NM, Hammond PM, Webber JF. Insect-fungus interactions. Academic Press, London, 25-68.

Hawker L, Madelin M. 1976 - The dormant spore. In: Weber DJ, Hess WM. The fungal spore. John Wiley \& Sons, New York, New York, 1-70.

Henis Y, Kenneth R, Barash I. 1987 - Survival and dormancy of fungi. In: Henis Y. Survival and dormancy of microorganisms. - Wiley, New York, 169-228. 
Henneberg L, 2004 - Biologie der Interaktion zwischen Koleopteren und agaricoiden Basidiomyzeten, doctoral thesis. Philipps-Universität Marburg.

Hess WM, Weber DJ. 1976 - Form and function in basidiomycete spores. In: Weber DJ, Hess WM. The fungal spore - form and function. - John Wiley and Sons., New York, 645-714.

Hibbett D, Grimaldi D, Donoghue M. 1997 - Fossil mushrooms from Miocene and Cretaceous ambers and the evolution of Homobasidiomycetes. American Journal of Botany 84(7), 981981.

Horton TR, Swaney DP, Galante TE. 2013 - Dispersal of ectomycorrhizal basidiospores: the long and short of it. Mycologia 105(6), 1623-1626.

Horton TR. 2006 - The number of nuclei in basidiospores of 63 species of ectomycorrhizal Homobasidiomycetes. Mycologia 98(2), 233-238.

Hudson HJ. 1991 - Fungal Biology. Cambridge University Press.

Hutchinson S, Kamel M. 1956 - The effect of earthworms on the dispersal of soil fungi. Journal of Soil Science 7(2), 213-218.

Ingold C. 1953 - Dispersal in fungi. Clarendon Press, Oxford.

Ingold C. 1966 - Aspects of spore liberation: violent discharge. In: Madelin M. The Fungus Spore. - Butterworths, London, 113-132.

Ingold CT. 1965 - Spore liberation. Clarendon Press (Oxford University Press), Oxford.

Ingold CT. 1971 - Fungal spores: Their liberation and dispersal. Clarendon Press, Oxford.

Janeau G, Cargnelutti B, Cousse S, Hewison M, Spitz F. 1995 - Daily movement pattern variations in wild boar (Sus scrofa L.). Ibex JME 3, 98-101.

Jastrow H. 2013 - Morphologie von Zellorganellen, Zellen und Geweben im Transmissionselektronenmikroskop. mainz.de/FB/Medizin/Anatomie/workshop/EM/eigeneEM/Vortrag/3/Bild1.jpg.

Jeffery S, Gardi C, Jones A, Montanarella L, Marmo L, Miko L, Ritz K, Peres G, Römbke J, Van der Putten W. 2010 - European atlas of soil biodiversity. European Commission.

Jennings DH, Lysek G. 1999 - Fungal biology: understanding the fungal lifestyle, 2nd edition. Bios Scientific Publishers Ltd.

Jeppesen JL. 1990 - Home range and movements of free-ranging roe deer (Capreolus capreolus) at Kalø. Ministry of the Environment, Division of Wildlife Ecology.

Johnson CN. 1996 - Interactions between mammals and ectomycorrhizal fungi. Trends in ecology \& evolution 11(12), 503-507.

Johnson D, Wellington W. 1983 - Dispersal of the collembolan, Folsomia candida Willem, as a function of age. Canadian journal of zoology 61(11), 2534-2538.

Jumpponen A. 2003 - Soil fungal community assembly in a primary successional glacier forefront ecosystem as inferred from rDNA sequence analyses. New Phytologist 158(3), 569-578.

Jurczyszyn M. 2006 - The use of space by translocated edible dormice, Glis glis (L.), at the site of their original capture and the site of their release: radio-tracking method applied in a reintroduction experiment. Polish Journal of ecology 54(3), 345-350.

Kauserud H, Colman JE, Ryvarden L. 2008 - Relationship between basidiospore size, shape and life history characteristics: a comparison of polypores. Fungal Ecology 1(1), 19-23.

Keller HW, Snell KL. 2002 - Feeding activities of slugs on Myxomycetes and macrofungi. Mycologia 94(5), 757-760.

Kendrick B. 1985 - The Fifth Kingdom. Mycologue Publications.

Kikkawa J. 1964 - Movement, activity and distribution of the small rodents Clethrionomys glareolus and Apodemus sylvaticus in woodland. The Journal of Animal Ecology, 259-299.

Kirk PM, Cannon PF, Minter DW, Stalpers JA. 2011 - Ainsworth \& Bisby's dictionary of the fungi, 10th edition. Cabi Publishing.

Knudsen H, Vesterholt J. 2012 - Funga Nordica: Agaricoid, boletoid, clavaroid, cyphelloid and gastroid genera. Nordsvamp.

Koivikko A, Savolainen J. 1988 - Mushroom allergy. Allergy 43(1), 1-10. 
Kramer C. 1982 - Production, release and dispersal of basidiospores. In: Frankland JC, Hedger JN, Swift MJ. Decomposer basidiomycetes: their biology and ecology. - Cambridge University Press, 33-49.

Kreisel H, Al-Fatimi M. 2008 - Further basidiomycetes from Yemen. Feddes Repertorium $119(5-6), 463-483$.

Kuo MJ, Alexander M. 1967 - Inhibition of the lysis of fungi by melanins. Journal of Bacteriology 94(3), 624-629.

Kuparinen A, Markkanen T, Riikonen H, Vesala T. 2007 - Modeling air-mediated dispersal of spores, pollen and seeds in forested areas. Ecological Modelling 208(2), 177-188.

Lacey J. 1986 - Water availability and fungal reproduction: patterns of spore production, liberation and dispersal. In: Ayres MP, Boddy L. Water, Fungi, and Plants. - Cambridge University Press, 65-86.

Lacey J. 1996 - Spore dispersal - its role in ecology and disease: the British contribution to fungal aerobiology. Mycological Research 100(6), 641-660.

Largent D, Johnson D, Watling R. 1978 - How to identify mushrooms to genus III: Microscopic features. Mad River Press, Eureka.

Levin SA, Ed. 2009: The Princeton Guide to Ecology. Princeton University Press, Princeton \& Oxford.

Li D-W. 2005 - Release and dispersal of basidiospores from Amanita muscaria var. alba and their infiltration into a residence. Mycological Research 109(11), 1235-1242.

Li D-W. 2011 - Five trillion basidiospores in a fruiting body of Calvatia gigantea. Mycosphere 2(4).

Li X-Y, Yang Z-P, Li Y-T, Lin H. 2009 - Connecting ecohydrology and hydropedology in desert shrubs: stemflow as a source of preferential flow in soils. Hydrology \& Earth System Sciences 13(7).

Lilleskov EA, Bruns TD. 2005 - Spore dispersal of a resupinate ectomycorrhizal fungus, Tomentella sublilacina, via soil food webs. Mycologia 97(4), 762-769.

Lösel DM. 1964 - The stimulation of spore germination in Agaricus bisporus by living mycelium. Annals of Botany 28(4), 541-554.

Lussenhop J. 1992 - Mechanisms of microarthropod-microbial interactions in soil. In: Begon M, Fitter A. Advances in Ecological Research, vol. 23. - Academic Press, 1-33.

Malloch D, Blackwell M. 1992 - Dispersal of fungal diaspores. In: Carroll GC, Wicklow DT. The fungal community: its organization and role in the ecosystem. - Marcel Dekker Inc., New York:, 147-171.

Manachère G, Robert J-C, Durand R, Bret JP, Fevre M. 1983 - Differentiation in the Basidiomycetes. In: Smith JE. Fungal Differentiation: a Contemporary Synthesis. - Marcel Dekker, New York, 481-514.

Maraun M, Visser S, Scheu S. 1998 - Oribatid mites enhance the recovery of the microbial community after a strong disturbance. Applied Soil Ecology 9(1), 175-181.

Maser C, Maser Z. 1988 - Interactions among squirrels, mycorrhizal fungi, and coniferous forests in Oregon. Western North American Naturalist 48(3), 358-369.

Mayhew PJ. 2006 - Discovering Evolutionary Ecology: Bringing Together Ecology and Evolution. Oxford University Press Oxford.

McKnight K. 1990 - Effect of low humidity on spore production and basidiocarp longevity among selected isolates of Flammulina velutipes. Mycologia 82(3), 379-384.

McLaughlin DJ. 1982 - Ultrastructure and cytochemistry of basidial and basidiospore development. In: Wells K, Wells EK. Basidium and basidiocarp. - Springer, New York, 37-74.

Meerts P. 1999 - The evolution of spore size in Agarics: do big mushrooms have big spores? Journal of Evolutionary Biology 12(1), 161-165.

Mitscherlich G. 1971 - Wald - Wachstum und Umwelt. 2. Waldklima und Wasserhaushalt. J.D. Sauerländer's Verlag, Frankfurt a.M. 
Moore D, Gange AC, Gange EG, Boddy L. 2008 - Fruit bodies: their production and development in relation to environment. In: Boddy L, Frankland J, West Pv. Ecology of saprotrophic basidiomycetes. - Elsevier - Academic Press, London, 79-103.

Moore D, Robson GD, Trinci APJ. 2011 - 21st Century Guidebook to Fungi. Cambridge University Press.

Moore D, Wai Chiu S, Halit Umar M, Sánchez C. 1998 - In the midst of death we are in life: further advances in the study of higher fungi. Transactions and Proceedings of the Botanical Society of Edinburgh and Botanical Society of Edinburgh Transactions 50(2), 121-135.

Moore D. 1998 - Fungal Morphogenesis. Cambridge University Press.

Moser M. 1993 - Fungal growth and fructification under stress conditions. Ukrainian Botanical Journal 50(3), 5-11.

Nakamori T, Suzuki A. 2007 - Defensive role of cystidia against Collembola in the basidiomycetes Russula bella and Strobilurus ohshimae. Mycological Research 111(11), 1345-1351.

Nara K. 2009 - Spores of ectomycorrhizal fungi: ecological strategies for germination and dormancy. New Phytologist 181(2), 245-248.

Nentwig W, Bacher S, Brandl R, Lay M. 2009 - Okologie Kompakt. Spektrum Akademischer Verlag $\mathrm{GmbH}$.

Nguyen NH, Hynson NA, Bruns TD. 2012 - Stayin' alive: survival of mycorrhizal fungal propagules from 6-yr-old forest soil. Fungal Ecology 5(6), 741-746.

Nordén J, Penttilä R, Siitonen J, Tomppo E, Ovaskainen O. 2013 - Specialist species of wood-inhabiting fungi struggle while generalists thrive in fragmented boreal forests. Journal of Ecology 101(3), 701-712.

Norros V, Rannik Ü, Hussein T, Petäjä T, Vesala T, Ovaskainen O. 2014 - Do small spores disperse further than large spores? Ecology 95(6), 1612-1621.

North M, Trappe J, Franklin J. 1997 - Standing crop and animal consumption of fungal sporocarps in Pacific Northwest forests. Ecology 78(5), 1543-1554.

Nosek J, Kožuch O, Chmela J. 1972 - Contribution to the knowledge of home range in common shrew Sorex araneus L. Oecologia 9(1), 59-63.

Nuss I. 1982 - Die Bedeutung der Proterosporen: Schlußfolgerungen aus Untersuchungen an Ganoderma (Basidiomycetes). Plant systematics and evolution 141(1), 53-79.

Oberwinkler F. 2012 - Evolutionary trends in Basidiomycota. Stapfia 96, 45-104.

Oliveira M, Ribeiro H, Delgado J, Abreu I. 2009 - The effects of meteorological factors on airborne fungal spore concentration in two areas differing in urbanisation level. International journal of biometeorology 53(1), 61-73.

Ou W, Liang W, Jiang Y, Li Q, Wen D. 2005 - Vertical distribution of soil nematodes under different land use types in an aquic brown soil. Pedobiologia 49(2), 139-148.

Parmasto E, Parmasto I, Möls T. 1987 - Variation of basidiospores in the Hymenomycetes and its significance to their taxonomy. J. Cramer.

Peay KG, Bruns TD. 2014 - Spore dispersal of basidiomycete fungi at the landscape scale is driven by stochastic and deterministic processes and generates variability in plant-fungal interactions. New Phytologist, DOI: 10.1111/nph.12906.

Peay KG, Schubert MG, Nguyen NH, Bruns TD. 2012 - Measuring ectomycorrhizal fungal dispersal: macroecological patterns driven by microscopic propagules. Molecular Ecology 21(16), 4122-4136.

Pegler DN, Fiard J. 1978 - Hygrocybe sect. Firmae (Agaricales) in tropical America. Kew Bulletin 32, 297-312.

Perrin N. 2009 - Dispersal. In: Levin SA. The Princeton Guide to Ecology. - Princeton University Press, Princeton \& Oxford, 45-50.

Plewińska B. 2007 - The effect of food odour on food preference, activity and density of dung beetle Geotrupes stercorosus (Scriba, 1791) in a mixed coniferous forest. Polish Journal of ecology 55(3), 495-509. 
Ponge J-F. 2000 - Vertical distribution of Collembola (Hexapoda) and their food resources in organic horizons of beech forests. Biology and fertility of soils 32(6), 508-522.

Pringle A, Patek SN, Fischer M, Stolze J, Money NP. 2005 - The captured launch of a ballistospore. Mycologia 97(4), 866-871.

Pringle A, Taylor JW. 2002 - The fitness of filamentous fungi. Trends in microbiology 10(10), 474-481.

Pringle A. 2013 - Asthma and the Diversity of Fungal Spores in Air. PLoS pathogens 9(6), e1003371.

Pyare S, Longland WS. 2001 - Patterns of ectomycorrhizal-fungi consumption by small mammals in remnant old-growth forests of the Sierra Nevada. Journal of Mammalogy 82(3), 681689.

Ramsbottom J. 1977 - Mushrooms \& Toadstools. Collins, London.

Rast D, Stäuble E. 1970 - On the mode of action of isovaleric acid in stimulating the germination of Agaricus bisporus spores. New Phytologist 69(2), 557-566.

Rast D, Stussi H, Hegnauer H, Nyhlen L. 1981 - Melanins. In: Turian G, Hohl HR. The Fungal Spore: Morphogenetic Controls. - Academic Press, London, 507-531.

Richardson M. 1970 - Studies on Russula emetica and other agarics in a Scots pine plantation. Transactions of the British Mycological Society 55(2), 217-229.

Riecken U, Raths U. 1996 - Use of radio telemetry for studying dispersal and habitat use of Carabus coriaceus L. Annales Zoologici Fennici 33(1), 109-116.

Robinson P, Park D, Graham T. 1968 - Autotropism in fungal spores. Journal of Experimental Botany 19(1), 125-134.

Roper M, Pepper RE, Brenner MP, Pringle A. 2008 - Explosively launched spores of ascomycete fungi have drag-minimizing shapes. Proceedings of the National Academy of Sciences 105(52), 20583-20588.

Ruddick SM, Williams ST. 1972 - Studies on the ecology of actinomycetes in soil V. Some factors influencing the dispersal and adsorption of spores in soil. Soil Biology and Biochemistry 4(1), 93-103.

Rühe F, Hohmann U. 2004 - Seasonal locomotion and home-range characteristics of European hares (Lepus europaeus) in an arable region in central Germany. European Journal of Wildlife Research 50(3), 101-111.

Ruiz-Herrera J. 2012 - Fungal Cell Wall: Structure, Synthesis, and Assembly, 2nd Edition. Taylor \& Francis, Boca Raton.

Schatz H. 1990 - Milbengesellschaften (Acari) von Auwaldböden aus dem Naturschutzgebiet Kufsteiner und Langkampfener Innauen (Tirol, Österreich) mit besonderer Berücksichtigung der Oribatida. Ber. nat.-med. Verein Innsbruck 77, 103-112.

Schickmann S, Urban A, Kräutler K, Nopp-Mayr U, Hackländer K. 2012 - The interrelationship of mycophagous small mammals and ectomycorrhizal fungi in primeval, disturbed and managed Central European mountainous forests. Oecologia, 1-15.

Schigel DS. 2012 - Fungivory and host associations of Coleoptera: a bibliography and review of research approaches. Mycology 3(4), 258-272.

Schwärzel K, Ebermann S, Schalling N. 2012 - Evidence of double-funneling effect of beech trees by visualization of flow pathways using dye tracer. Journal of Hydrology 470, 184-192.

Shaw P. 1992 - Fungi, fungivores, and fungal food webs. In: Carroll GC, Wicklow DT. The Fungal Community. Its Organization and Role in the Ecosystem. - Marcel Dekker, Inc., New York, 295-310.

Shuttleworth WJ. 1977 - The exchange of wind-driven fog and mist between vegetation and the atmosphere. Boundary-Layer Meteorology 12(4), 463-489.

Sinsch U. 1988 - Seasonal changes in the migratory behaviour of the toad Bufo bufo: direction and magnitude of movements. Oecologia 76(3), 390-398.

Smith SE, Read DJ. 2008 - Mycorrhizal symbiosis. Academic Press.

Sowerby J. 1797 - Coloured Figures of English Fungi or Mushrooms Vol. 1. J. Davis. 
Spooner BM, Roberts PJ. 2005 - Fungi. Harper UK.

Spori DM, Drobek T, Zürcher S, Ochsner M, Sprecher C, Mühlebach A, Spencer ND. 2008 Beyond the Lotus Effect: Roughness Influences on Wetting over a Wide Surface-Energy Range. Langmuir 24(10), 5411-5417.

Stevens VM, Turlure C, Baguette M. 2010 - A meta-analysis of dispersal in butterflies. Biological Reviews 85(3), 625-642.

Stocks D, Hess W. 1970 - Ultrastructure of dormant and germinated basidiospores of a species of Psilocybe. Mycologia 62, 176-191.

Stolze-Rybczynski JL, Cui Y, Stevens MHH, Davis DJ, Fischer MWF, Money NP. 2009 Adaptation of the spore discharge mechanism in the Basidiomycota. PloS one 4(1), e4163.

Sussman AS, Halvorson HO. 1966 - Spores, their dormancy and germination. Harper \& Row, New York.

Swinbank P, Taggart J, Hutchinson SA. 1964 - The Measurement of Electrostatic Charges on Spores of Merulius Lacrymans (Wulf.) Fr. Annals of Botany 28(2), 239-249.

Tanghe LJ, Hillhouse E. 1973 - Dependence of spore shape on maturity of carpophore in the Phalloidae section of Amanita. McIlvainea 1, 1-8.

Taylor AF, Alexander I. 2005 - The ectomycorrhizal symbiosis: life in the real world. Mycologist 19(3), 102-112.

Taylor TN, Krings M, Taylor EL. 2014 - Fossil Fungi. Elsevier Science.

Tello S, Silva-Flores P, Agerer R, Halbwachs H, Beck A, Peršoh D. 2013 - Hygrocybe virginea is a systemic endophyte of Plantago lanceolata. Mycological Progress Sept. 2013, DOI 10.1007/s11557-013-0928-0.

Thomas P. 1981 - Migration of Longidorus elongatus, Xiphinema diversicadatum and Ditylenchus dipsaci in soil. Nematologia mediterranea 9, 75-81.

Timoféeff-Ressovsky NW, Timoféeff-Ressovsky EA. 1941 - Populationsgenetische Versuche An Drosophila. Zeitschrift für Induktive Abstammungs- und Vererbungslehre 79(1), 35-43.

Tulloss RE. 2005 - Amanita-Distribution in the Americas, with comparison to eastern and southern Asia and notes on spore character variation with latitude and ecology. Mycotaxon 93, 189231.

Turner J, Webster J. 1991 - Mass and momentum transfer on the small scale: how do mushrooms shed their spores? Chemical engineering science 46(4), 1145-1149.

Van Etten J, Dahlberg K, Russo G. 1983 - Fungal spore germination. In: Smith JE. Fungal Differentiation. A Contemporary Synthesis. - Marcel Dekker, Inc., New York, Basel, 235266.

Vellinga EC. 2004 - Ecology and Distribution of Lepiotaceous Fungi (Agaricaceae) - A Review. Nova Hedwigia 78(3-4), 273-299.

Watling R. 1988 - Larger fungi and some of earth's major catastrophies. In: Boddy L, Watling R, Lyon AJE. Fungi and ecological disturbance. - The Royal Society of Edinburgh, 49-59.

Wauters L, Dhondt AA. 1992 - Spacing behaviour of red squirrels, Sciurus vulgaris: variation between habitats and the sexes. Animal Behaviour 43(2), 297-311.

Weber H. 1993 - Allgemeine Mykologie. Gustav Fischer Jena.

Webster J, Davey R, Duller G, Ingold C. 1984 - Ballistospore discharge in Itersonilia perplexans. Transactions of the British Mycological Society 82(1), 13-29.

Webster J, Weber R. 2007 - Introduction to fungi. Cambridge Univ Press.

Wiese V. 2014 - Die Landschnecken Deutschlands: Finden Erkennen Bestimmen. Quelle + Meyer.

Wigglesworth V. 1957 - The physiology of insect cuticle. Annual Review of Entomology 2(1), 3754.

Wolf FA, Wolf FT. 1947 - The fungi. J. Wiley, New York.

Wösten H, Wessels J. 1997 - Hydrophobins, from molecular structure to multiple functions in fungal development. Mycoscience 38(3), 363-374.

Zellner J. 1907 - Chemie der höheren Pilze. W. Engelmann. 